\title{
Crustal and uppermost mantle shear-wave velocity structure beneath the Middle East from surface-wave tomography
}

\author{
Ayoub Kaviani ${ }^{1}$, Anne Paul ${ }^{2}$, Ali Moradi ${ }^{3}$, Paul Martin Mai ${ }^{4}$, Simone Pilia ${ }^{5}$, Lapo Boschi ${ }^{6,7,8}$, Georg \\ Rümpker ${ }^{1}$, Yang $\mathrm{Lu}^{2}$, Zheng Tang ${ }^{4}$, Eric Sandvol ${ }^{9}$ \\ ${ }^{1}$ Institute of Geosciences, Goethe-University Frankfurt, Frankfurt/Main, Germany \\ ${ }^{2}$ Univ. Grenoble Alpes, Univ. Savoie Mont Blanc, CNRS, IRD, IFSTTAR, ISTerre, Grenoble 38041, \\ France \\ ${ }^{3}$ Institute of Geophysics, University of Tehran, Tehran, Iran \\ ${ }^{4}$ Earth Science and Engineering Program, Physical Science and Engineering Division, King Abdullah \\ University of Science and Technology (KAUST), Thuwal, Kingdom of Saudi Arabia \\ ${ }^{5}$ Department of Earth Sciences, University of Cambridge, Cambridge, UK \\ ${ }^{6}$ Dipartimento di Geoscienze, Università degli Studi di Padova, Italy \\ ${ }^{7}$ Institut des Sciences de la Terre de Paris, Sorbonne Université, CNRS-INSU, ISTeP UMR 7193, \\ Paris, France \\ ${ }^{8}$ Istituto Nazionale di Geofisica e Vulcanologia, Bologna, Via Donato Creti, 12, 40128 Bologna, \\ Italy \\ ${ }^{9}$ Department of Geological Sciences, University of Missouri-Columbia, USA
}

\begin{abstract}
We have constructed a 3-D shear-wave velocity (Vs) model for the crust and uppermost mantle beneath the Middle East using Rayleigh wave records obtained from ambient-noise crosscorrelations and regional earthquakes. We combined one decade of data collected from 852 permanent and temporary broadband stations in the region to calculate group-velocity dispersion curves. A compilation of $>54000$ ray paths provides reliable group-velocity measurements for periods between 2 and $150 \mathrm{~s}$. Path-averaged group velocities calculated at different periods were inverted for 2-D group-velocity maps. To overcome the problem of heterogeneous ray coverage, we used an adaptive grid parametrization for the group-velocity tomographic inversion. We then sample the period-dependent group-velocity field at each cell of a predefined grid to generate 1-D group-velocity dispersion curves, which are subsequently inverted for 1-D Vs models beneath each cell and combined to approximate the 3-D Vs structure of the area. The Vs model shows low velocities at shallow depths $(5-10 \mathrm{~km})$ beneath the Mesopotamian foredeep, South Caspian Basin, eastern Mediterranean and the Black Sea, in coincidence with deep sedimentary basins.
\end{abstract}


Shallow high-velocity anomalies are observed in regions such as the Arabian Shield, Anatolian Plateau and Central Iran, which are dominated by widespread magmatic exposures. In the 10-20 $\mathrm{km}$ depth range, we find evidence for a band of high velocities $(>4.0 \mathrm{~km} / \mathrm{s})$ along the southern Red Sea and Arabian Shield, indicating the presence of upper mantle rocks. Our 3-D velocity model exhibits high velocities in the depth range of $30-50 \mathrm{~km}$ beneath western Arabia, eastern Mediterranean, Central Iranian Block, South Caspian Basin and the Black Sea, possibly indicating a relatively thin crust. In contrast, the Zagros mountain range, the Sanandaj-Sirjan metamorphic zone in western central Iran, the easternmost Anatolian plateau and Lesser Caucasus are characterized by low velocities at these depths. Some of these anomalies may be related to thick crustal roots that support the high topography of these regions. In the upper mantle depth range, high-velocity anomalies are obtained beneath the Arabian Platform, southern Zagros, Persian Gulf and the eastern Mediterranean, in contrast to low velocities beneath the Red Sea, Arabian Shield, Afar depression, eastern Turkey and Lut Block in eastern Iran. Our Vs model may be used as a new reference crustal model for the Middle East in a broad range of future studies.

Key Words: Tomography, Crustal imaging, Seismic interferometry, Surface waves and free oscillations, Structure of the Earth, Crustal structure

\section{Introduction}

The current tectonic setting of the Middle East was mainly formed during the latest collisional stage of the Alpine tectonic cycle associated with the Arabia-Eurasia collision (e.g. Allen et al., 2004). The continued convergence between the Arabian and Eurasian plates is currently accommodated by thrusting and folding in the sediments, thrust faulting in the basement and thickening of the lower crust in mountain belts, principally Zagros, Alborz, Kopeh Dagh and Greater and Lesser Caucasus, as well as by strike-slip motions across the Anatolian and Iranian Plateaus. Part of the shortening in the Zagros is also accommodated by lithosphere thickening (Priestley et al., 2012). As the result, the modern tectonic framework of the Middle East is defined by an assembly of different plate boundary types (Allen et al., 2004; Le Pichon and Kreemer, 2010; Reilinger and McClusky, 2011). These include: 1) active subduction zones along the Hellenic and Cyprus trenches in the west and Makran in the east, 2) continental collision zones: Zagros-Bitlis, Alborz, Kopeh Dagh and Lesser and Greater Caucasus, 3) lithosphere-scale 
strike-slip faults such as the Northern and Eastern Anatolian Fault zones and the Dead-Sea continental transform fault, and systems of strike-slip faults in eastern Iran, and 4) spreading centers in the Red Sea and the Gulf of Aden (Figure 1).

The presence of such a broad variety of plate boundaries and tectonic settings provides an ideal opportunity to investigate the dynamic interaction between these tectonic systems. To this end, a comprehensive knowledge of the lithospheric structure of the region is essential.

Numerous regional tomography studies have provided information on upper mantle structures beneath different regions of the Middle East (e.g. Kaviani et al., 2007; Biryol et al., 2011; Salaün et al., 2012; Simmons et al., 2015; Portner et al., 2018; Tang et al., 2016, 2018, 2019). However, because of data access limitations, these studies have often been limited by political boundaries. In the past few years, crustal structure has been studied in different parts of the Middle-East region using receiver function analysis and surface-wave tomography (e.g. Zor et al., 2003; Paul et al., 2006, 2010; Hammond et al., 2011; Vanacore et al., 2013; Delph et al, 2015; Tang et al., 2018, 2019; Rastgoo et al., 2018; Karabulut et al., 2019). Warren et al. (2013) and Delph et al (2015) investigated the crustal structure of the Turkish-Anatolian Plateau using ambient-noise tomography, but their models do not have adequate resolution along the outer limits of the study area because they only used stations located inside Turkey. Motaghi et al. (2013) carried out the first ambient-noise tomography of the crustal structure of the Iranian plateau using data from a sparse array. Their images display large-scale tectonic features of the Iranian Plateau, but with low resolution due to poor ray coverage. Recently, Movaghari and Doloei (2019) conducted a Rayleigh-wave phase-velocity tomography based on ambient-noise analysis to investigate the crustal and upper-mantle structure beneath the Iranian Plateau and Zagros. Their shear-wave velocity model provides evidence for crustal thickening beneath the Zagros and high-velocity upper mantle beneath the SE Zagros. However, due to the data coverage limit, their model does not have sufficient resolution at the boundary regions. Pilia et al. (2020) used a relatively dense and new passive seismic network in the United Arab Emirates, together with a number of stations in south-central Iran. By using a sophisticated inversion scheme applied to seismic noise they were able to image the crust beneath the southeastern Zagros, providing evidence for underthrusting of the Arabian basement beneath central Iran and 3-D variations in the sediment cover of the Zagros mountains. Priestley and McKenzie (2013) used long-period surface waves to provide seismic images of the upper mantle beneath the broader Middle-East region, but their resolution was not sufficient to delineate features at scales smaller than a few hundred $\mathrm{km}$, 
particularly in the crust. Kaviani et al. (2015) used an integrated Lg waveform data set to map attenuation and velocity structure in the crust across the Middle East. However, due to the nature of the $\mathrm{Lg}$ wave, the average crustal models have no depth resolution.

In this study, we aim at providing the first high-resolution crustal shear-wave velocity (Vs) model of the broader Middle-East region computed with a robust method and homogeneous parameters. The computed velocity model has potential for a variety of purposes including geological interpretation, seismic hazard assessment, earthquake location and geodynamic modelling. Due to the broad extent of the Vs model, we cannot discuss all its outcomes here. Therefore, we focus our comments on a few regions to either outline differences with other models in well-studied areas (Anatolia), or discuss the main features of less well-studied areas (Iran and Arabia).

Furthermore, an important missing piece of information about the lithospheric structure in the Middle East is a comprehensive map of the crustal thickness. Knowledge of crustal thickness variations is essential for a vast field of studies including seismic hazard assessment and numerical simulation of lithospheric deformation. A major objective of our study is to provide such an integrated crustal thickness map for the entire Middle East.

\section{Data and methodology}

\subsection{Data}

We conducted surface-wave tomography and inversion for shear-wave velocity to image the crustal and uppermost mantle structure of the entire Middle-East region. The majority of the surface-wave dispersion data was obtained by analysis of continuous seismic ambient noise (AN) collected from 709 broadband stations (blue triangles in Figure 2) operated in the Middle East over the last two decades. Cross-correlations of long-term background noise records at simultaneously recording stations yield an estimate of the empirical Green's function between station pairs (Lobkis and Weaver, 2001; Campillo and Paul, 2003; Shapiro and Campillo, 2004; Campillo and Roux, 2014; Boschi and Weemstra, 2015). The analysis and subsequent tomographic inversion of surface-wave dispersion data derived from ambient-noise crosscorrelation provide a high-resolution image of the lithospheric structure beneath a dense network of seismometers (Sabra et al. 2005; Shapiro et al. 2005; Bensen et al. 2007). In this study, the interstation distance for AN analysis varies between 20 and $5000 \mathrm{~km}$. Our raw data covers the years 1994-2000 and 2007-2015. We follow the standard procedure described by Bensen et al. (2007) and modified by Boué et al. (2014) to compute the vertical component cross-correlation 
functions (CCF) between all station pairs (for more information see the Supplementary Information). A gather of computed CCF is shown in Supplementary Figure S1. The final CCF are exploited as Rayleigh wave records between stations and standard frequency-time analysis (FTAN) is applied to extract group-velocity dispersion curves. Examples of this analysis are shown in Supplementary Figure S2.

In regions where continuous seismic noise records were not available, such as Saudi Arabia, we incorporated dispersion curve data from previous studies to improve ray coverage. We used the dispersion measurements by Tang et al. (2018, 2019) for Rayleigh waves (periods 8-75s) observed at 143 permanent broadband stations of the Saudi National Seismic Network (SNSN) (green triangles in Figure 2) for regional earthquakes (EQ) located inside our study area. The inclusion of these EQ-based dispersion data dramatically improves the ray coverage across Arabia (Figure S3).

The two sets of dispersion curves (from AN and EQ) overlap in the period range 8-75s for paths crossing Saudi Arabia. To avoid biasing the group-velocity maps by multiple measurements along paths close to each other and to assess the consistency of path-averaged measurements, we followed a clustering procedure in which all similar paths are clustered to make a single path. This procedure is explained in detail in the Supplementary Information.

\subsection{Surface wave tomography}

In order to constrain group-velocity variations at different periods, we construct 2-D groupvelocity maps from our path-averaged measurements. Our algorithm is based on that of Boschi and Dziewonski (1999). The inversion algorithm is discussed in detail by Lu et al. (2018). As shown by the examples in Supplementary Figure S3, we are dealing with heterogeneous ray coverage across the study area. Following previous studies (Schaefer et al., 2011; Auer et al., 2014; and Lu et al., 2018) we employed the adaptive-cell version of Boschi and Dziewonski's (1999) algorithm. In this approach, the cell size in each part of the model space is adjusted according to the ray density. This helps secure an optimal resolution for each part of the inverted model depending on ray coverage. After several preliminary tests based on visual inspection, we selected varying cell sizes of $0.25^{\circ}, 0.5^{\circ}$, and $1.0^{\circ}$; a few examples of the adaptive cell size maps are shown in Supplementary Figure S4.

We perform tomographic inversion for periods between 2 and $150 \mathrm{~s}$. At each period, the inversion is carried out in two steps. We first invert all measured group traveltimes using a high 
damping value to detect incoherent measurements. Then we discard all paths with traveltime residual (difference between observed traveltime and traveltime predicted from the over-damped model) higher than 3 times the mean traveltime residual of all paths. Following this procedure, about $30 \%$ of ray paths are discarded as outliers at each period. The second round of groupvelocity tomography is then carried out using the remaining paths. The average group velocity of all paths at each period is used as the starting model for inversion. In the inversion algorithm, the trade-off between data fitting and model resolution is controlled by a damping parameter and a roughness coefficient whose values $(0.3$ and 0.1$)$ are chosen based on an L-curve test (Hansen, 2001).

To assess the resolution power of the data set and inversion approach, we performed several synthetic tests using the same raypath configuration as the observational data set. The results of synthetic tests at several periods are shown in Supplementary Figure S5. These tests reveal that features as small as $1^{\circ}$ can be resolved in most parts of the study area at periods from 10 to $36 \mathrm{~s}$, while features of size $2^{\circ}$ are resolved fairly well in the entire period range throughout the study area. A more detailed description of results of the synthetic tests is given in the Supplementary material.

In Figure 3, we present group-velocity maps at few selected periods. These maps delineate many features related to the crustal structure. However, in order to provide more geologically meaningful interpretations, we invert these group-velocity maps for 3-D shear-wave velocity (Vs) model. The Vs model is described and discussed in detail in the next sections.

Since we combine two data sets (dispersion curves from ambient-noise (AN) and earthquakes (EQ)), one important issue about the results shown in Figure 3 is how the inclusion of the EQbased dispersion data affects our results. In order to verify this, we show in Figure S6 group velocity maps (at the same periods shown in Figure 3), which are obtained only using AN-based dispersion data. The comparison between the group velocity maps shown in Figures 3 and S6 reveals that no significant difference between the results are observed at period range less than 25 sec. The main difference is observed at periods 36-46 sec for the region of the Arabian Shield, where the inclusion of the EQ-based dispersion data tends to shift the group velocities to higher values. Since the ray coverage in the case of the combined data set is much better than solely the AN-based data, we conclude that the inclusion of the EQ-based data helps to suppress the effects of the low-velocity outliers in these period ranges. 


\subsection{Inversion for shear-wave velocity}

We adopted a modified version of the algorithm of $\mathrm{Lu}$ et al. (2018) to invert group-velocity dispersion data for depth-dependent models of shear-wave speed (Vs), by extracting dispersion curves at $0.25^{\circ}$ intervals from the group-velocity maps (Figure 3 ). As shown by the resolution tests (Supplementary Figure S5), resolution is best at $18 \mathrm{~s}$ period. We therefore select a cell for inversion if the number of rays crossing the cell at $18 \mathrm{~s}$ is larger than 50. In addition, the number of crossing rays at all other periods should be larger than 10 .

The 1-D inversion of dispersion curves for Vs was performed in two steps. Examples of this twostep inversion approach are shown in Supplementary Figure S7 for two cells in Iran and Arabia. We first followed a Bayesian algorithm to find an optimum 1-D model, which was then used as starting model for a linearized inversion. Our probabilistic inversion is based on the Bayesian algorithm introduced by Bodin et al. (2012) and modified by Lu et al. (2018). It is summarized in the Supplementary Information. In this approach, we first created a library of more than 14 million random models and computed their dispersion curves. The random models have 5 layers (4 crustal layers over a half space). Shear-wave velocity and thickness of each layer were randomly changed to generate the set of initial models. The plausible range of variation of velocity and thickness of each layer was defined using the reference model CRUST1.0 (Laske et al., 2013) and a priori information from previous studies (e.g. Paul et al., 2006, 2010; Delph et al., 2015). The P-wave velocity (Vp) and density of each layer were calculated using the empirical relationships (1) and (9) of Brocher (2005). We use equations (9) and (1) of Brocher (2005) to calculate, respectively, the Vp (from Vs) and density (from Vp). The ranges of thickness and Vs variations are given in Table 1. The velocity of the bottom half space was calculated by random variation around the uppermost mantle velocity of the standard Earth model IASP91 (Kennett and Engdahl, 1991). The Bayesian inversion was performed for a maximum period of $100 \mathrm{~s}$.

In the second step, we computed, for each cell, the average of the 1-D models resulted from the Bayesian inversion and used it as the starting model for the linearized inversion (Herrmann, 2013). The whole range of periods up to 150 s was used in the linear inversion. As shown by Supplementary Figure S7, the lower (mantle) part of the input velocity model is modified by the linear inversion while the upper (crustal) part changes much less. Finally, the 1-D models obtained from the two-step inversion of all cells are combined in a quasi-3-D final Vs model. 


\section{Results}

In this section we present depth slices of our final 3-D Vs model on the scale of the entire study area (Figure 4). The group-velocity maps shown in Figure 3 correspond to periods that are mostly sensitive to Vs at the depths shown in Figure 4, in order to outline the correspondence between the original group-velocity maps and the final Vs model (see sensitivity kernels of the linear inversion in Supplementary Figure S8).

\subsection{Shear wave velocity maps}

Our Vs model exhibits slow velocities at shallow depths (down to $15 \mathrm{~km}$ ) in the regions of thick sedimentary basins such as the Mesopotamian Foredeep, Persian Gulf, Eastern Mediterranean, and the Black Sea (Figure 4). High-velocity regions are observed in the shallow crust beneath the Arabian Shield, the Afar depression, central Iran and parts of the Anatolian Plateau where magmatic crystalline rocks are present at shallow depths and/or the crust is relatively thin. The southern Red Sea and Arabian Shield exhibit upper mantle velocities (Vs $>4.1 \mathrm{~km} / \mathrm{s}$ ) at a depth of $15 \mathrm{~km}$ indicative of a very thin crust. These features also appear in the group velocity maps at periods of 10-18 s (Figure 3).

At depths around $25 \mathrm{~km}$ (corresponding to a period of $25 \mathrm{~s}$, Figure 3), the Vs map shows upper and mid crustal velocities beneath the Iranian and Anatolian Plateaus, and upper mantle velocities beneath Afar, the Red Sea, the Gulf of Aden, and the Aegean Sea. A strong low-velocity anomaly is mapped in the easternmost Mediterranean Sea both in Figure 3 at 8-25 s and Figure 4 at 10-25 $\mathrm{km}$. It could be due to the presence of a very thick sedimentary basin; however, the resolution in that area is not sufficient to guarantee the reliability of this anomaly.

In the depth range of $35-45 \mathrm{~km}$, we observe upper mantle velocities (Vs>4.1 km/s) beneath the western and northern Arabian Plate and the Dead Sea, the Aegean Sea, the Black Sea, the Caspian Sea and Turan Plate. Crustal velocities (Vs $<4.0 \mathrm{~km} / \mathrm{s}$ ) are mapped beneath the mountain belts in Iran and Eastern Turkey, due to their thick crust. The high-velocity region of the Eastern Mediterranean and northern Arabia has a sharp northern boundary that coincides with the surface trace of the Cyprus trench and Zagros-Bitlis suture zone. Low velocities are also found in SW Turkey within the Isparta Angle that could be related to the assumed slab tear.

At depths $>45 \mathrm{~km}$ most regions are characterized by upper mantle velocities. A NW-SE elongated low-velocity strip is mapped at 55 and $70 \mathrm{~km}$ depth beneath the Iranian-Turkish plateaus that may be due to crustal thickening. The maps at 45 and $55 \mathrm{~km}$ depth reveal that the 
southern Red Sea has relatively low upper mantle velocities while the northern Red Sea has a faster upper mantle. The Afar region is characterized by low mantle velocities $(3.9-4.0 \mathrm{~km} / \mathrm{s})$ surrounded by regions of low velocities beneath the SE Red Sea, SW Yemen and the westernmost Gulf of Aden. Cyprus is also characterized by low velocities at 45-55 km, probably due to its thicker crust than the surrounding Eastern Mediterranean Sea. At depths $\geq 70 \mathrm{~km}$ (Figure 4), our Vs model exhibits features that are comparable with the regional tomography models (e.g. Hansen et al., 2012; Priestley and McKenzie, 2013; Simmons et al., 2015). A wide region of slow-velocity upper mantle is mapped beneath the Afar depression, southern Red Sea and SW Arabia that possibly indicates ascending hot material and/or partial melting. Several high-velocity anomalies are mapped beneath the SE Zagros and Persian Gulf and the stable cratonic regions of the Eurasian plate. The features mapped at large depths also appear on the group velocity maps of Figure 3 though long period group velocities are sensitive to a wide depth range. We will discuss specific parts of our 3-D Vs model in more detail in section 4.

\subsection{Moho Map}

We extracted a Moho depth map based on the inversion processes for Vs models. We first extracted a preliminary Moho map during the Bayesian probabilistic inversion. At each cell, we used the probability for having an interface and searched for the shallowest interface between 10 and $70 \mathrm{~km}$ where $\mathrm{Vs}$ increases from crustal $(\mathrm{Vs} \leq 3.5 \mathrm{~km} / \mathrm{s})$ to upper mantle velocity (Vs $\geq 4.1$ $\mathrm{km} / \mathrm{s}$ ). The resulting depth map was then visually checked by examining its lateral continuity and consistency with the velocity boundaries in the final 3-D Vs model. The Moho depth at each cell was manually corrected if required. In Figure 5, we compare the resulting Moho map with that from the global reference model CRUST1.0 (Laske et al., 2013). The grid spacing in CRUST1.0 is $1.0^{\circ}$, while it varies between $0.25^{\circ}$ and $1.0^{\circ}$ in our study. Our Moho map shown in Figure 5 a is resampled at $0.5^{\circ}$. At first glance, the two maps exhibit similarities in large-scale features such as thick crust beneath mountain belts and easternmost Turkey, and relatively thin crust beneath the Red Sea, Mediterranean Sea and Black Sea. However, our high-resolution Moho map exhibits several features that differ significantly from the reference map. For example, a wide area of thick crust is located beneath the Zagros suture in the CRUST1.0 model. Our model, however, shows that the crust beneath the Zagros is less than $45 \mathrm{~km}$ thick and that crustal thickening actually occurs within a relatively narrow strip located NE of the suture, in better agreement with receiver function studies (Paul et al., 2006, 2010). Another contrasting feature is the thinner crust 
beneath the South Caspian Basin (SCB) and Turan plate $(<35 \mathrm{~km})$, which is more than $40 \mathrm{~km}$ in CRUST1.0. Furthermore, CRUST1.0 features a relatively smooth Moho beneath the Anatolian Plateau while our Moho map has significant local topography and larger depth values. The thickest crust across the Turkish-Anatolian Plateau is detected beneath the East Anatolian Accretionary Complex (EAAC) and eastern Caucasus. The Moho in the Dead Sea region has an average depth of $\sim 30 \mathrm{~km}$, in agreement with previous receiver function analysis (e.g. Mohsen et al., 2011). The Arabian Plate has relatively thin crust (<35 km in average) except in the SE part. The relatively thin crust of the Arabian plate contrasts with the thicker crust beneath the deforming front of the Platform in the Zagros-Bitlis fold-and-thrust belt. The thinnest crust is observed along the Red Sea in both models. Our model, however, suggests that a thin (possibly oceanic?) crust has developed beneath the SE part of the Red Sea while the NW part is still underlain by a regular continental-type crust. We discuss this observation in more detail in the following section.

\section{Discussion}

It is beyond the scope of this paper to discuss in detail the crustal structure of each sub-region. Therefore, we chose to focus on three sub-regions and discuss the results with respect to the tectonic setting and in comparison with previous geophysical studies. Since extensive studies have already been conducted on the crustal and mantle structure of the Turkish-Anatolian Plateau, we briefly discuss the results in this area by comparison with previous studies. We then discuss in more detail our results on the crustal structure of the Iranian Plateau and Zagros, and the Arabian Plate.

\subsection{Turkish-Anatolian Plateau}

The low velocity at the $8-\mathrm{km}$ depth slice (Figure 4) suggests a relatively thick sedimentary fill in the Black Sea and a very thick sedimentary basin in the eastern Mediterranean. Apart from a few small-size sedimentary basins, crystalline rocks constitute most of the shallow upper crust beneath the Anatolian Plateau. A wide region of low velocities appears in western Anatolia at depths 15-25 km that suggests a low-velocity mid-lower crust. Figure 4 also shows that eastern Turkey is overall characterized by a low Vs crustal and uppermost mantle relative to Central Anatolia in agreement with previous regional seismic tomography (e.g. Biryol et al., 2011; Salaün et al., 2012; Portner et al., 2018). This can be explained by syn- and post-collisional 
volcanism (Keskin, 2003). The crust in western Anatolia is much slower than in any other region in Turkey, which is likely a consequence of the extensional tectonics in the region, as it was also suggested by previous studies (e.g. Delph et al, 2015).

In Figures 6 and S9, we present several vertical slices through the 3-D velocity model across Anatolia. We also show Moho profiles from our study (solid black lines) in comparison with that from CRUST1.0 model (dashed black lines) and the recent receiver functions study (solid white lines) of Karabulut et al. (2019). In Supplementary Figure S10 we present vertical slices through the 3-D probability density model for the depth of interfaces along the same profiles as in Figures 6 and S9. The deepest high-probability interfaces imaged along the profiles indicate the trace of the Moho.

Recent ambient-noise tomography studies (Warren et al., 2013; Delph et al, 2015) showed that the Turkish-Anatolian Plateau is characterized by lateral seismic velocity variations that correlate with the geological boundaries and suture zones. Our tomography is in general agreement with these studies, though it provides more details on the deep crust and the Moho topography. In contrast with Delph et al. (2015), our extensive regional ray coverage allows us to map the shearwave velocity beneath the Turkish-Anatolian Plateau and its adjacent areas, such as Black Sea and the Caucasus in the north, Eastern Mediterranean Sea and Arabian Plate in the south, and Iranian Plateau and Zagros in the east. For example, the boundary between the Anatolian block and the Arabian plate that corresponds to the Bitlis suture and the East Anatolian Fault on the surface (Figure 1) is clearly marked by a sharp velocity change beneath the suture at different depth levels (Figures 4, 6 and S9). In their inversion of ambient-noise dispersion data to Vs, Delph et al (2015) used a priori constraints on the crustal thickness from the receiver function study by Vanacore et al. (2013). Our Bayesian approach, however, allows constraining the Moho depth directly from dispersion data, independently of any other model.

Our inversion method and uniform data coverage reveal strong lateral changes of the velocity in the lower crust of the Anatolian Plateau and a rough Moho topography. These strong lateral variations in Moho depth are visible in the interface probability function (Supplementary Figure S10). Our Moho map (Figure 5) and vertical slices (Figures 6, S9 and S10) confirm the general west-to-east deepening of the Moho documented by previous studies (e.g. Zor et al., 2003; Vanacore et al., 2013; Karabulut et al., 2019), but with stronger small-scale topography. Karabulut et al. (2019) showed that the crust thickens very regularly from west to east beneath the Anatolian Plateau, which led them to propose that an initially rough Moho topography may 
have been smoothed out by viscous flow in the lower crust. By contrast, our Moho model is rather irregular.

\subsection{Iranian Plateau and Zagros}

The Iranian Plateau and Zagros encompass several main structural units including the mountain belts of Zagros, Alborz and Kopeh Dagh, the Central Iranian block, the Sanandaj-Sirjan metamorphic zone (SSZ), the Urumieh-Dokhtar magmatic arc (UDMA) and the Makran subduction zone (Figure 1). The Zagros Fold-and-Thrust Belt (ZFTB) marks the deformational front on the passive margin of the Arabian Plate. In the ZFTB, 8-13 km thick Phanerozoic sedimentary sequences cover the underlying pre-Cambrian basement of the Arabian platform (see Allen et al., 2013 and references therein). The SSZ represents a tectono-magmatic and metamorphic zone that extends from the Bitlis area in Turkey to the western boundary of the Makran active subduction zone in SE Iran and is made up mainly of sedimentary and metamorphic rocks of Paleozoic to Cretaceous age (Stöcklin, 1968; Agard et al., 2011). The most accepted hypothesis is that the SSZ delineates the former active margin of an Iranian microplate (Berberian and King, 1981). The Main Zagros Thrust (MZT) that separates ZFTB and SSZ is regarded as the suture zone between the former Arabian passive margin and central Iran (e.g. Agard et al., 2011, Paul et al., 2006, 2010). The UDMA situated between the SSZ and Central Iran is a zone of extensive Tertiary magmatic activity, with a record of peak activity in the Middle Eocene (Berberian and King, 1981).

A strip of low velocity region is mapped at depths $\geq 35 \mathrm{~km}$ parallel to the Zagros belt that shifts toward the NE beneath the SSZ and UDMA at depths $\sim 55 \mathrm{~km}$ (Figure 4). This is an indication for a progressive thickening of the crust toward the NE at the suture between the Arabian Plate and the Iranian-Turkish plateau. The Moho map of Figure 5 also documents a thick crust ( $\geq 45 \mathrm{~km})$ beneath the mountain belts (Zagros, Alborz and Kopeh Dagh) and thinner crust $(25-35 \mathrm{~km})$ in northern Central Iran and southern Caspian Sea.

In Figure 7, we present vertical slices through the 3-D velocity model across the Zagros belt and the Iranian Plateau, with comparisons of our Moho depth estimates (solid black lines) with CRUST1.0 model (dashed black lines). Figure 8 shows the same vertical slices through the interface probability density model. Our model exhibits small-scale Moho topography unresolved in CRUST1.0. The crustal thickening to the NE of the MZT (profiles I1 to I5) supports the hypothesis of underthrusting of the Arabian crust beneath Central Iran as proposed by previous 
studies (Paul et al., 2006, 2010; Motaghi et al., 2017a; Mahmoodabadi et al., 2019). Two interfaces at the base of the sediments and at $\sim 20 \mathrm{~km}$ depth are clearly identified in the velocity and interface probability density slices (Figures 7 and 8). The middle and lower crust beneath the Zagros exhibit relatively lower velocities than Central Iran and the undeformed parts of the Arabian Platform. This difference may result from stronger deformation of the Zagros crust due to continental collision, although a compositional difference cannot be ruled out.

In the depth range of 35-45 $\mathrm{km}$ (Figure 4), upper mantle velocities appear beneath the Mesopotamian Foredeep, indicative of a relatively thin crust. Vertical cross-sections I2-I4 (Figures 7 and 8) also display this Moho uplift beneath the Mesopotamian Foredeep and Persian Gulf that contrasts with the NE deepening of the Moho beneath the Zagros and SSZ. This largescale undulation of the Moho may support the flexural bending model proposed by Pirouz et al. (2017).

The uppermost mantle beneath the SSZ, UDMA, Central Iran and Alborz is overall marked by lower velocities than Zagros and Turan plate (Figure 4). Previous studies (e.g. Kaviani et al., 2007, Motaghi et al., 2015; Mahmoodabadi et al., 2019) suggest that this velocity contrast can be observed down to a depth of $250 \mathrm{~km}$. A high-velocity uppermost mantle is mapped beneath the southern Zagros and Persian Gulf (slices 70-90 km in Figure 4; profiles I4 and I5, Figure 7). Maggi and Priestley (2005) and Kaviani et al. (2007) also imaged a high-velocity region in the upper mantle beneath the Central Zagros that was later defined as the "Zagros Core" by Priestley et al. (2012). Our images suggest that this high velocity anomaly is likely located only beneath the Persian Gulf and southern Zagros.

To the north, our velocity maps (Figure 4) and vertical cross-sections (C1, I1, I2, Figures 7 and 8) suggest that the crust beneath the Alborz is on average thinner than $45 \mathrm{~km}$. The Alborz mountain belt separates the relatively stable South Caspian Basin (SCB) in the north from the Central Iranian Block in the south (Allen et al., 2004). Despite its high relief, the Alborz mountain belt shows no evidence for a thick crustal root. Our velocity model also suggests that the SCB has a relatively thin (less than $40 \mathrm{~km}$ ) and relatively low-velocity crust that lies over a high-velocity upper mantle (Figure 4 and profile $\mathrm{C}$ in Figure 7). The SCB is taken as an aseismic and possibly rigid block surrounded by actively deforming belts (Jackson et al., 2002; Allen et al., 2003; 2004). In a broader prospect, the SCB also comprises the Kura basin to the west and the western Turkmenian depression to the east. Figure 4 shows that the velocity anomalies of the SCB crust extend beneath the Kura basin to the west and Turkmenian depression to the east, but they have 
sharp lateral boundaries with the Alborz and Talesh at all depths. The values of the absolute shear velocities suggest that the top few kilometers of the SCB crust are likely formed by unconsolidated Quaternary sediments that merge to more consolidated and crystalline rocks at a depth of $\sim 20 \mathrm{~km}$. The lower crust beneath the SCB exhibits low velocities probably indicating a felsic (granitic) composition. Previous studies (Zonenshain and Le Pichon, 1986; Mangino and Priestley, 1998; Knapp, et al., 2004) suggest that a "basaltic" layer could be present beneath the proposed "granitic" layer. If this "basaltic" layer exists, it is probably too thin to be detected by the surface waves used in this study.

Farther to the NE, the vertical cross-sections I3, I4 and I6 (Figures 7 and 8) show that the crust is relatively thin $(<40 \mathrm{~km})$ beneath north Central Iran and that it thickens northward to $\sim 45 \mathrm{~km}$ over a wide region beneath the Kopeh Dagh and Binalud mountains. Farther NE, the crust becomes as thin as $30 \mathrm{~km}$ beneath the Turan Plate. Interestingly, the sharp NE limit of the Kopeh Dagh Mountains on the surface coincides with the steep gradient in Moho depth (Figures 5, 7 and 8). The Kopeh Dagh Mountains in NE Iran form an NW-SE trending fold-and-thrust belt between Central Iran and the stable Turan (Turkmenistan) Platform of Eurasia (Shabanian et al., 2009). Structurally, the crust of the Kopeh Dagh belongs to the Turan platform (Alavi 1996). The Binalud Mountains to the south of Kopeh Dagh mark the northeastern margin of Central Iran and the suture with Kopeh Dagh (Eurasia; Alavi 1992, 1996). Our Vs model suggests that the presentday lithosphere structure beneath the Kopeh Dagh is distinct from the Turan plate and exhibits more similarities with the central Iranian lithosphere.

Our velocity maps and vertical slices (Figure 4; profiles I5 and I6 in Figure 7) show a lowvelocity uppermost mantle $(\mathrm{Vs} \leq 4.1 \mathrm{~km} / \mathrm{s})$ beneath the Lut block in eastern Iran. The Lut block acts as a rigid block bounded by strike-slip fault systems (Jackson and McKenzie, 1984; Berberian, 2005; Jackson et al., 2006; Javadi et al., 2015). The location of velocity contrasts coincide with the surface expression of the major strike-slip faults such as Doruneh fault that marks the boundary between the Lut Block and northern Central Iran and Kopeh Dagh (Javadi et al., 2015). The rather low velocities immediately beneath the crust in our images may also suggest that the upper mantle beneath the Lut Block is overall hotter than the surrounding regions.

The Makran Subduction Zone (MSZ), which extends from southeast Iran to southern Pakistan, includes an accretionary wedge where the Tethys oceanic lithosphere connected to the Arabian plate is subducting beneath the Eurasian Plate (e.g. Farhoudi and Karig 1977; Şengör et al. 1988; 
Byrne et al. 1992). In the crustal depth range ( $<40 \mathrm{~km}$ ), our model suggests very low velocities to $20 \mathrm{~km}$ depth beneath the Makran, which are likely related to thick Cenozoic turbidites and younger Quaternary detrital sediments filling the accretionary wedge (Burg, 2018). The Moho depth is $\sim 40 \mathrm{~km}$ beneath the coast line increasing northward to $\sim 50 \mathrm{~km}$ beneath the Lut block (profiles I6 and I7, Figure 7). Our model does not have sufficient resolution to constrain the geometry of the subducting slab in the Makran.

\subsection{Arabian Plate, the Red Sea and Afar depression}

The Arabian Plate consists of two major domains: the Arabian Shield in the west and the Arabian Platform in the east. The boundary at the surface is locally identified along the remnants of the Late Proterozoic orogen (Stoeser \& Camp 1985). The crust of the Arabian Shield is composed primarily of several tectonostratigraphic terranes that were accreted during the Neoproterozoic (Stoeser \& Camp 1985; Camp \& Roobol, 1992; Johnson and Woldehaimanot, 2003). The Precambrian basement rocks are exposed at the surface in the Arabian Shield with virtually no sedimentary cover. The crust of the Arabian Shield was also affected by Cenozoic volcanism and uplift. The Cenozoic volcanism is mostly flood basalts, which likely have a causal link to the rifting processes in the Red Sea and Afar (Coleman and McGuire, 1988). In the Arabian Platform, however, a thick succession of Phanerozoic sedimentary rocks covers the Precambrian basement. The sedimentary cover in the Arabian Platform gradually thickens eastward and reaches more than $10 \mathrm{~km}$ thickness beneath the Mesopotamian Foredeep and Persian Gulf (Seber 1997).

Our velocity maps and vertical slices (Figures 4, 9 and S11) suggest that on average the Arabian Shield has higher crustal seismic velocities than the Arabian Platform, in agreement with previous studies (Hansen et al., 2007, 2008; Chang and Van der Lee, 2011; Tang et al., 2016, 2018, 2019). The velocity map at 8-km depth (Figure 4) exhibits high velocities beneath the Arabian Shield and Afar depression where magmatic crystalline rocks are exposed at shallow depths. At $\sim 15 \mathrm{~km}$, a wide region of very high velocities (Vs>4.0 km/s) is mapped beneath the southeastern Red Sea, the western Arabian Shield and the Gulf of Aden, which may indicate the presence of mantle rocks at shallow depths. This high-velocity layer is imaged from a highvelocity peak in the group-velocity dispersion curves (see example shown in Figure S7). Our verification with the AN-based and EQ-based dispersion data (Figures 3 and S6) indicates that this layer is a robust feature in our model. We suggest that the presence of such a shallow high- 
velocity layer beneath the Arabian Shield is the result of lateral spreading of mantle material coming up beneath the Red Sea. At $25-\mathrm{km}$ depth, the high velocity anomaly is confined to the SE Red Sea, while the other regions of western Arabia and northwest Red Sea exhibit low velocities $(3.5<\mathrm{Vs}<4 \mathrm{~km} / \mathrm{s})$. Our velocity model generally suggests that northern and western Arabia and the Dead Sea region have structural similarities with the Arabian Shield. For example, the 35-km depth map (Figure 4) shows that all these regions exhibit mantle velocities at this depth, while further east the Arabian Platform has crustal velocities (Vs $<4.0 \mathrm{~km} / \mathrm{s}$ ). The northern boundary of the Arabian Plate with the Turkish-Anatolian Plateau across the Bitlis suture zone is marked by strong velocity contrasts at all depths (depths slices $15-70 \mathrm{~km}$, Figure 4). In addition, our model shows that the crustal structure beneath the Arabian Shield and Red Sea is more complex than previously thought. Previous seismic imaging studies (e.g. Rodgers et al., 1999; Tkalčić et al., 2006; Park et al., 2007, 2008; Hansen et al., 2007, 2008; Chang and Van der Lee, 2011; Tang et al., 2016, 2018, 2019) suggested that the crust thickens rapidly eastward from less than $25 \mathrm{~km}$ beneath the western Arabian Shield and Red Sea to 40-45 km beneath the central region of the Arabian Shield. In contrast, our Vs model reveals a very complex crustal structure beneath the Red Sea and Arabian Shield, so that the Moho can hardly be identified (Figures 9, S11 and S12).

\subsubsection{Widespread regional mantle flow beneath Afar, Red Sea, W. Arabia}

At depths $\geq 55 \mathrm{~km}$ (Figure 4), a low-velocity anomaly is mapped beneath the SE Red Sea that extends laterally at 70-km depth to cover the Afar depression, Red Sea, south and SW Arabia. At greater depths $(90 \mathrm{~km})$, this widespread low-velocity region extends northward and likely connects to the low-velocity region beneath eastern Turkey. Previous global and regional seismic tomography studies (e.g. Ritsema and Allen, 2003; Bastow et al., 2008; Hansen et al., 2012; Hammond et al., 2013) suggest that the broad low-velocity region in the upper mantle beneath eastern Africa, Afar, and western Arabia likely results from shallow decompression melting and northeastward flow of the African superplume material. Our model also shows a broad lowvelocity region in the uppermost mantle beneath the southern Red Sea and Arabia Shield that might be related to the wider mantle upwelling beneath Afar. Our model also favors the hypothesis of a northward channeled flow in the uppermost mantle beneath the western Arabian Shield that was also proposed by previous studies (e.g. Park et al., 2007, 2008; Hansen et al., 2007, 2008, 2012; Chang and Van der Lee, 2011; Tang et al., 2016, 2018, 2019; Kaviani et al. 2018). Petrological studies of Cenozoic rocks in the Arabian Shield (Duncan et al., 2016; Downs 
et al., 2018) also support the hypothesis of a northward mantle flow. This possible northward flow of the upwelled material affects not only the upper mantle but also the crustal structure beneath the Red Sea and Arabian Shield. One important question that seismic tomography studies have attempted to address is the mechanism of emplacement of Cenozoic volcanism in the Arabian Shield (Hansen et al., 2007, 2008; Chang and Van der Lee, 2011; Koulakov et al., 2016; Yao et al., 2017; Tang et al., 2016, 2018, 2019). Tang et al., (2019) and Koulakov et al., (2015) argue that the crustal low-velocity zones imaged beneath the western Arabian Shield may reflect weakened zones in the crust caused by magma ascent rather than significant partial melt or steady-state crustal reservoir. We also propose that instead of being from large-scale crustal magma chambers, the magma intrusion beneath the Arabian shield is mainly sourced from the large-scale mantle flow as suggested above.

\subsubsection{Different structures in northern and southern Red Sea?}

The velocity maps of Figure 4 reveal that the southern $\left(12^{\circ} \mathrm{N}-21^{\circ} \mathrm{N}\right)$ and northern $\left(>21^{\circ} \mathrm{N}\right)$ parts of the Red Sea exhibit very different characteristics in terms of crustal and upper mantle structure. At shallow depths $(10-20 \mathrm{~km})$, the southern Red Sea shows higher Vs than the northern Red Sea. The shallow high-velocity layer of the southern Red Sea extends eastward beneath the Arabian Shield rather than along the Red Sea. At depths below $\sim 35 \mathrm{~km}$, the situation is opposite, with lower velocities beneath the southern Red Sea than beneath the northern Red Sea (Figures 4, 9 and S11). The upper boundary of the low-velocity zone is marked by a negative velocity gradient as indicated by red color in the interface probability sections (Supplementary Figure S12). Our Vs model suggests a transition from a mostly continental crust in the northern Red Sea to an oceanic crust in the southern Red Sea. Recent geophysical and offshore drilling data also highlight this structural difference between the northern and southern segments of the Red Sea (Mitchell and Park, 2014; Bonatti et al., 2015). These observations suggest that the crust beneath the northern Red Sea is likely undergoing late stages of continental rifting, while southern Red Sea is in a stage of sea floor spreading.

The driving force for the rifting and sea floor spreading in the Red Sea has long been a subject of debate. Two end-member mechanisms are proposed: passive and active rifting. In passive rifting model, spreading is driven by far-field forces such as slab pull from Zagros subduction (Koulakov et al., 2016; Yao et al., 2017). In active rifting model, spreading is driven by local mantle upwelling (e.g. Hansen et al., 2007). Koulakov et al. (2016) suggested passive rifting 
because they observed a high P-wave velocity anomaly in the upper mantle beneath the Red Sea. Their velocity anomaly is mainly located beneath the central part of the Red Sea. A thick lowvelocity zone is mapped in our images beneath southwestern Yemen (NE of the Bab el Mandeb Strait) that extends down to a depth of $\sim 60 \mathrm{~km}$, where is likely the location of active partial melting and magma generation. In connection to the wider mantle flow at greater depths, it seems that active mantle upwelling is confined to the southern Red Sea. Based on these observations, we hypothesize that active mantle upwelling is the main contributor to sea floor spreading in the southern Red Sea. GPS observations (e.g. ArRajehi et al., 2010) also suggest a faster extension rate in the southern than in the northern Red Sea, in support of an active rifting in the southern Red Sea. In the northern Red Sea, passive rifting appears to be the dominant mechanism and mantle upwelling has a secondary role. The rift axis in the NW seems to be shifted to the eastern flank of the Red Sea and beneath the western margin of the Arabian Shield rather than centered at the Red Sea ridge as was also suggested by Chang et al. (2013).

\section{Conclusions}

We used an integrated data set and a robust inversion approach to construct a 3-D shear-wave velocity (Vs) model for the broader region of the Middle East. Our tomographic images of crustal and upper mantle velocity structure cover the region from western Turkey to eastern Iran in the EW direction and from Afar depression to Caucasus Mountains in the NS direction. Our model provides relatively high-resolution images of various tectonic units constituting the crustal structure of the Middle East and reveals the transitions, both laterally and vertically, between these crustal units.

The crustal and uppermost mantle structure beneath the Anatolian Plateau and eastern Turkey concurs with the main features shown by previous studies. The extent of the low-velocity crust beneath the western Anatolian Plateau, likely related to the extensional tectonics of the region, and the low-velocity uppermost mantle beneath eastern Turkey are very well resolved in our model. The Moho exhibits local-scale topography beneath western Anatolia; a point that should be taken into consideration in future studies.

Our velocity model provides relatively high-resolution images of the crustal and uppermost mantle structure beneath the Iranian Plateau and Zagros. It delineates along-strike variation of the crustal structure beneath the Zagros, which can be indicative of different stages of crustal thickening. Furthermore, we observe evidence for under-thrusting of the Arabian crust beneath 
Central Iran, with varying structure along the suture line. The crust beneath Central Iran is relatively thin (less than $40 \mathrm{~km}$ ). Our velocity model also suggests that a crustal root is lacking beneath the Alborz mountains in northern Iran. In eastern Iran, we image a relatively lowvelocity uppermost mantle beneath the Lut Block, which could indicate a hot upper mantle but it requires higher resolution imaging to be confirmed.

The velocity model also provides relatively high-resolution images of the crustal structure beneath the Arabian Platform and Shield, Red Sea and Afar. These images suggest that while the crust beneath the SE Red Sea exhibits oceanic characteristics, the crust beneath the NW part seems to have a continental affinity. A relatively high-velocity layer is present extensively at the mid-crustal depths beneath the Arabian Shield that likely originates from the mantle material upwelling beneath the central ridge of the Red Sea and spreading to the east and NE beneath the Shield. The Cenozoic magmatic activity in the Arabian Shield may be sourced from the hot material flowing beneath the Shield at different depth levels.

Our integrated 3-D Vs model and crustal thickness map of the Middle East provide a foundation for future studies in different disciplines including local crustal studies, earthquakes location and seismic hazard assessment, and first order constraints for geodynamic modeling. The digital Moho map is provided as Supplementary material for future references. The 3-D Vs model is made available online through the IRIS (Incorporated Research Institutions for Seismology) Earth Model Collaboration (IRIS DMC, 2011) (http://ds.iris.edu/ds/products/emc-earthmodels/) with the label Midd_East_Crust_1.

\section{Acknowledgment}

The authors would like to thank three anonymous reviewers for providing valuable comments and suggestions that improved the initial and revised versions of the manuscript.

This study was possible thanks to the availability of continuous daily record of seismic noise from permanent and temporary stations operating in the region. Data was provided by different seismological networks and data centers. The Iranian Seismological Center (Institute of Geophysics, University of Tehran) and International Institute of Earthquake Engineering and Seismology (IIEES) gratefully provided the daily noise record from the permanent broadband stations in Iran. Continuous records from Kandilli Observatory Digital Broadband Seismic Network (doi: 10.7914/SN/KO, Kandilli Observatory and Earthquake Research Institute, Bosphorus Univ. (2001)) and Israeli Broadband Seismological Network (GII-Net, network code 
IS) were downloaded from the European Integrated Data Archive (EIDA). The facilities of IRIS Data Services and specifically the IRIS Data Management Center were used to access data of temporary stations and global permanent stations used in this study. IRIS Data Services are funded through the Seismological Facilities for the Advancement of Geoscience and EarthScope (SAGE) Proposal of the National Science Foundation under cooperative agreement EAR1261681. The seismological networks providing data to us via the IRIS data service are listed in the Supplementary Information.

Rayleigh wave group-velocity dispersion data from the Saudi National Seismic Network (SNSN) operated by the Saudi Geological Survey was taken from previous studies (Tang et al., 2018, 2019) of the seismology group (PMM and ZT) from the King Abdullah University of Science and Technology (KAUST). PMM and ZT were supported by grant BAS/1/1339-01-01 funded by the KAUST.

We adopted the algorithm introduced by Boué et al. (2014) and used the WHISPER software package (Briand et al., 2013) to preprocess individual daily vertical-component records. Seismic analysis was conducted using the routines implemented in the Python package ObsPy (Beyreuther et al, 2010).

The maps shown in the paper were created using the Generic Mapping Tools (Wessel et al., 2013).

S.P. acknowledges support from Natural Environmental Research Council (NERC) grant NE/R013500/1 and from the European Union's Horizon 2020 research and innovation program under Marie Skłodowska-Curie grant agreement 790203. S.P. is grateful to the NCM for providing continuous passive seismic data used in this study.

\section{References}

Agard, P., Omrani, J., Jolivet, L., Whitechurch, H., Vrielynck, B., Spakman, W., Wortel, R. (2011). Zagros orogeny: A subduction-dominated process. Geological Magazine, 148(5-6), 692-725. doi:10.1017/S001675681100046X.

Alavi, M. (1992), Thrust tectonics of the Binalood Region, NE Iran, Tectonics, 11(2), 360-370, doi: 10.1029/91TC02217.

Alavi, M., 1996. Tectonostratigraphic synthesis and structural style of the Alborz mountain system in northern Iran, J. Geodyn., 21(1), 1-33, https://doi.org/10.1016/0264-3707(95)00009-7.

Allen, M. B., C. Saville, E. J.-P. Blanc, M. Talebian, and E. Nissen (2013), Orogenic plateau growth: Expansion of the Turkish-Iranian Plateau across the Zagros fold-and-thrust belt, Tectonics, 32, 171-190, doi:10.1002/tect.20025.

Allen, M., J. Jackson, and R. Walker (2004), Late Cenozoic reorganization of the Arabia-Eurasia collision and the comparison of short-term and long-term deformation rates, Tectonics, 23, TC2008, doi: 10.1029/2003TC001530. 
Allen, M.B., Vincent S.J, Alsop G.I., Ismail-zadeh A., and R. Flecker R., 2003, Late Cenozoic deformation in the South Caspian region: effects of a rigid basement block within a collision zone, Tectonophysics, 366, 223-239, https://doi.org/10.1016/S0040-1951(03)00098-2.

ArRajehi, A., S. McClusky, R. Reilinger, M. Daoud, A. Alchalbi, S. Ergintav, F. Gomez, J. Sholan, F. Bou Rabee, and G. Ogubazghi (2010), Geodetic constraints on present-day motion of the Arabian Plate: Implications for Red Sea and Gulf of Aden rifting, Tectonics, 29, TC3011, doi:10.1029/2009TC002482.

Auer, L., Boschi, L., Becker, T. W., Nissen-Meyer, T., Giardini, D. (2014), Savani: A variable-resolution whole-mantle model of anisotropic shear-velocity variations based on multiple datasets, J. Geophys. Res., 119, 3006--3034, doi:10.1002/2013JB010773.

Bastow, I. D., A. A. Nyblade, G. W. Stuart, T. O. Rooney, and M. H. Benoit (2008), Upper mantle seismic structure beneath the Ethiopian hot spot: Rifting at the edge of the African low-velocity anomaly, Geochem. Geophys. Geosyst., 9, Q12022, doi: 10.1029/2008GC002107.

Bensen G.D., Ritzwoller M.H., Barmin M.P., Levshin A.L., Lin F., Moschetti M.P., Shapiro N.M., Yang Y., 2001, A fast and reliable method for surface wave tomography. Geophys. J. Int. 169, 1239-1260, doi: 10.1111/j.1365-246X.2007.03374.x.

Berberian M., (2005), The 2003 Bam Urban Earthquake: A Predictable Seismotectonic Pattern Along the Western Margin of the Rigid Lut Block, Southeast Iran. Earthquake Spectra: December 2005, Vol. 21, No. S1, pp. 35-99, https://doi.org/10.1193/1.2127909.

Berberian, M., and G. C. P. King (1981), Towards a paleogeography and tectonic evolution of Iran, Can. J. Earth Sci., 18, 210-265, https://doi.org/10.1139/e81-019.

Beyreuther, M., Barsch, R., Krischer, L., Megies, T., Behr, Y. \& Wassermann, J., 2010. ObsPy: a python toolbox for seismology, Seism. Res. Lett., 81(3), 530-533.

Biryol, B. C., Beck, S. L., Zandt, G., \& Özacar, A. A. (2011). Segmented African lithosphere beneath the Anatolian region inferred from teleseismic P-wave tomography. Geophysical Journal International, 184(3), 1037-1057. https://doi.org/10.1111/j.1365-246X.2010.04910.x.

Bodin, T., Sambridge, M., Rawlinson, N. \& Arroucau, P., 2012. Transdimensional tomography with unknown data noise, Geophys. J. Int., 189(3), 1536-1556, https://doi.org/10.1111/j.1365246X.2012.05414.X.

Bonatti E., Cipriani A., Lupi L. (2015) The Red Sea: Birth of an Ocean. In: Rasul N., Stewart I. (eds) The Red Sea. Springer Earth System Sciences. Springer, Berlin, Heidelberg.

Boschi, L., and A. M. Dziewonski (1999), High- and low-resolution images of the Earth's mantle: Implications of different approaches to tomographic modeling, J. Geophys. Res., 104(B11), 25567-25594, doi: 10.1029/1999JB900166.

Boschi, L., C. Weemstra (2015), Stationary-phase integrals in the cross-correlation of ambient noise, Rev. Geophys., 53, doi:10.1002/2014RG000455.

Bosworth, W., P. Huchon, and K. McClay (2005), The Red Sea and Gulf of Aden Basins, J. Afr. Earth. Sci., 43(1-3), 334-378, https://doi.org/10.1016/j.jafrearsci.2005.07.020.

Boué P., Poli P., Campillo M., Roux P., 2014, Reverberations, coda waves and ambient-noise: correlations at the global scale and retrieval of the deep phases. Earth planet. Sci. Lett., 391, 137-145, https://doi.org/10.1016/j.epsl.2014.01.047.

Brocher, T.M., 2005. Empirical relations between elastic wavespeeds and density in the Earth's crust, Bull. seism. Soc. Am., 95(6), 2081-2092, https://doi.org/10.1785/0120050077.

Burg, J.P., 2018. Geology of the onshore Makran accretionary wedge: synthesis and tectonic interpretation. Earth-Sci. Rev. 185, 1210-1231. https://doi.org/10.1016/j.earscirev.2018.09.011. 
Byrne, D. E., L. R. Sykes, and D. M. Davis (1992), Great thrust earthquakes and aseismic slip along the plate boundary of the Makran Subduction Zone, J. Geophys. Res., 97(B1), 449-478, doi: 10.1029/91JB02165.

Camp, V. E., and M. J. Roobol (1992), Upwelling asthenosphere beneath western Arabia and its regional implications, J. Geophys. Res., 97(B11), 15255-15271, doi: 10.1029/92JB00943.

Campillo, M., and P. Roux (2014), Seismic imaging and monitoring with ambient noise correlations, in Treatise of Geophysics. Vol. 1, edited by B. Romanowicz and A. M. Dziewonski, Elsevier.

Chang, S. J., \& Van der Lee, S. (2011). Mantle plumes and associated flow beneath Arabia and East Africa. Earth and Planetary Science Letters, 302(3), 448-454, https://doi.org/10.1016/j.epsl.2010.12.050.

Chang, S.-J., Merino, M., Van der Lee, S., Stein, S., and Stein, C. A. (2011), Mantle flow beneath Arabia offset from the opening Red Sea, Geophys. Res. Lett., 38, L04301, doi:10.1029/2010GL045852.

Coleman, R. G., and A. V. McGuire (1988), Magma systems related to the Red Sea opening, Tectonophysics, 150, 77-100, doi: 10.1016/0040-1951(88)90296-X.

Delph, J. R., Biryol, C. B., Beck, S. L., Zandt, G., and Ward, K. M. (2015), Shear wave velocity structure of the Anatolian Plate: Anomalously slow crust in southwestern Turkey, Geophys. J. Int., 202, 261-276, doi:10.1093/gjiras/ggv141.

Downs, D. T., Stelten, M. E., Champion, D. E., Dietterich, H. R., Nawab, Z., Zahran, H., Hassan, K., \& Shawali, J. (2018). Volcanic history of the northernmost part of the Harrat Rahat volcanic field, Saudi Arabia. Geosphere, 14(3), 1253- 1282. https://doi.org/10.1130/GES01625.1

Duncan, R. A., Kent, A. J., Thornber, C. R., Schlieder, T. D., \& Al-Amri, A. M. (2016). Timing and composition of continental volcanism at Harrat Hutaymah, western Saudi Arabia. Journal of Volcanology and Geothermal Research, 313, 1-14. https://doi.org/10.1016/j.jvolgeores.2016.01.010

Farhoudi G. Karig D.E., 1977. Makran of Iran and Pakistan as an active arc system, Geology, 5, 664 -668 https://doi.org/10.1130/0091-7613(1977)5<664:MOIAPA>2.0.CO;2.

Hammond, J. O. S., J.-M. Kendall, G. W. Stuart, D. Keir, C. Ebinger, A. Ayele, and M. Belachew (2011), The nature of the crust beneath the Afar triple junction: Evidence from receiver functions, Geochem. Geophys. Geosyst., 12, Q12004, doi: 10.1029/2011GC003738.

Hammond, J.O.S., Kendall, J.-M., Stuart, G.W., Ebinger, C.J., Bastow, I.D., Keir, D., Ayele, A., Belachew, M., Goitom, B., Ogubazghi, G., Wright T.J., 2013, Mantle upwelling and initiation of rift segmentation beneath the Afar Depression, Geology, 41, 635-638. doi: https://doi.org/10.1130/G33925.1.

Hansen, P., 2001, The L-curve and its use in the numerical treatment of inverse problems, in Computational Inverse Problems in Electrocardiography, Vol. 5, pp. 119-142, ed. Johnston, P., WIT Press.

Hansen, S. E., J. B. Gaherty, S. Y. Schwartz, A. J. Rodgers, and A. M. S. Al-Amri (2008), Seismic velocity structure and depth-dependence of anisotropy in the Red Sea and Arabian shield from surface wave analysis, J. Geophys. Res., 113, B10307, doi:10.1029/2007JB005335.

Hansen, S. E., Rodgers, A., Schwartz, S. and Al-Amri, A. (2007). Imaging ruptured lithosphere beneath the Red Sea and Arabian Peninsula. Earth and Planetary Science Letters. 259. 256-265. 10.1016/j.epsl.2007.04.035.

Hansen, S.E., Nyblade, A.A., and Benoit, M.H., 2012, Mantle structure beneath Africa and Arabia from adaptively parameterized P-wave tomography: Implications for the origin of Cenozoic Afro-Arabian tectonism: Earth and Planetary Science Letters, v. 319-320, doi:10.1016/j.epsl.2011.12.023.

Jackson, J., and McKenzie, D., 1984, Active tectonics of the Alpine-Himalayan Belt between western Turkey and Pakistan, Geophys. J. Int., 77, 185-264, https://doi.org/10.1111/j.1365-246X.1984.tb01931.x. 
Jackson, J., M. Bouchon, E. Fielding, G. Funning, M. Ghorashi, D. Hatzfeld, H. Nazari, B. Parsons, K. Priestley, M. Talebian, M. Tatar, R. Walker, T. Wright, 2006, Seismotectonic, rupture process, and earthquake-hazard aspects of the 2003 December 26 Bam, Iran, earthquake, Geophys. J. Int., 166, 12701292, https://doi.org/10.1111.

Jackson, J., Priestley, K., Allen, M. and Berberian, M. (2002), Active tectonics of the South Caspian Basin. Geophys. J. Int., 148: 214-245. doi:10.1046/j.1365-246X.2002.01005.x.

Javadi, H. R., M. Esterabi Ashtiani, B. Guest, A. Yassaghi, M. R. Ghassemi, M. Shahpasandzadeh, and A. Naeimi (2015), Tectonic reversal of the western Doruneh Fault System: Implications for Central Asian tectonics, Tectonics, 34, 2034-2051, doi: 10.1002/2015TC003931.

Johnson P. R. and Woldehaimanot B., 2003, Development of the Arabian-Nubian Shield: perspectives on accretion and deformation in the northern East African Orogen and the assembly of Gondwana, Geological Society, London, Special Publications, 206, 289-325, https://doi.org/10.1144/GSL.SP.2003.206.01.15.

Karabulut, H., Paul, A., Değer Özbakır, A., Ergün, T., Şentürk, S., 2019, A new crustal model of the Anatolia-Aegean domain: evidence for the dominant role of isostasy in the support of the Anatolian plateau, Geophysical Journal International, 218, 57-73, https://doi.org/10.1093/gji/ggz147.

Kaviani, A., Paul, A., Bourova, E., Hatzfeld, D., Pedersen, H., \& Mokhtari, M. (2007). A strong seismic velocity contrast in the shallow mantle acrossthe Zagros collision zone (Iran). Geophysical Journal International, 171(1), 399-410. https://doi.org/10.1111/j.1365-246X.2007.03535.X

Kaviani A., Sandvol E., Bao X., Rümpker G., Gök R., 2015, The structure of the crust in the TurkishIranian Plateau and Zagros using Lg Q and velocity, Geophys. J. Int., 200, 1252-1266, https://doi.org/10.1093/gji/ggu468.

Kaviani, A., Sandvol, E., Moradi, A., Rümpker, G., Tang, Z., \& Mai, P. M. (2018). Mantle transition zone thickness beneath the Middle-East: Evidence for segmented Tethyan slabs, delaminated lithosphere, and lower mantle upwelling. Journal of Geophysical Research: Solid Earth, 123, 4886- 4905. https://doi.org/10.1029/2018JB015627.

Kennett B.L.N. and Engdahl E.R., 1991, Travel times for global earthquake location and phase association, Geophysical Journal International, 105:429-465, doi:10.17611/DP/9991809.

Keskin, M., 2003. Magma generation by slab steepening and breakoff beneath a subduction-accretion complex: an alternative model for collision-related volcanism in Eastern Anatolia, Turkey, Geophys. Res. Lett., 30(24), 8046, doi:10.1029/2003GL018019.

Knapp, C. C., J. H. Knapp, and J. A. Connor (2004), Crustal-scale structure of the South Caspian Basin revealed by deep seismic reflection profiling, Mar. Pet. Geol., 21(8), 1073-1081, https://doi.org/10.1016/j.marpetgeo.2003.04.002.

Koulakov, I., Burov, E., Cloetingh, S., El Khrepy, S., Al-Arifi, N., \& Bushenkova, N. (2016). Evidence for anomalous mantle upwelling beneath the Arabian Platform from travel time tomography inversion. Tectonophysics, 667, 176- 188. https://doi.org/10.1016/j.tecto.2015.11.022.

Koulakov, I., El Khrepy, S., Al-Arifi, N., Kuznetsov, P., \& Kasatkina, E. (2015). Structural cause of a missed eruption in the Harrat Lunayyir basaltic field (Saudi Arabia) in 2009. Geology, 43(5), 395-398. https://doi.org/10.1130/G36271.1

Laske, G., Masters, G., Ma, Z. \& Pasyanos, M., 2013. Update on CRUST1.0 - a 1-degree global model of Earth's crust, in Geophysical Research Abstracts EGU General Assembly, Vienna, Austria, Vol. 15, pp. 2013-2658. 
Le Pichon X. and Kreemer C., 2010, The Miocene to present kinematic evolution of the Eastern Mediterranean and Middle-East and its implications for dynamics, Ann. Rev. Earth planet. Sci. , 38 , 323 -351 , doi:10.1146/annurev-earth-040809-152419.

Lobkis, O.I. and Weaver R.L., 2001. On the emergence of the Greens function in the correlations of a diffuse field , J. acoust. Soc. Am. , 110 , 3011-3017; https://doi.org/10.1121/1.1417528.

Lu, Y., Stehly, L., Paul, A., and AlpArray Working Group, 2018, High-resolution surface wave tomography of the European crust and uppermost mantle from ambient seismic noise, Geophysical Journal International, 214, 1136-1150, https://doi.org/10.1093/gii/ggy188.

Maggi, A. and Priestley, K. (2005), Surface waveform tomography of the Turkish-Iranian plateau. Geophysical Journal International, 160: 1068-1080. doi:10.1111/j.1365-246X.2005.02505.x.

Mahmoodabadi, M., Yaminifard, F., Tatar, M., Kaviani, A., Motaghi, K., 2019, Upper-mantle velocity structure beneath the Zagros collision zone, Central Iran and Alborz from nonlinear teleseismic tomography, Geophysical Journal International, 218, 414-428, https://doi.org/10.1093/gji/ggz160.

Mangino, S., \& Priestley, K. (1998). The crustal structure of the southern Caspian region. Geophys. J. Int., 133, 630-648, https://doi.org/10.1046/j.1365-246X.1998.00520.x.

Mitchell, N.C:, Park, Y., 2014, Nature of crust in the central Red Sea, Tectonophysics, 628, 123-139, https://doi.org/10.1016/j.tecto.2014.04.029.

Mohsen, A., G. Asch, J. Mechie, R. Kind, R. Hofstetter, M. Weber, M. Stiller, and K. Abu- Ayyash (2011), Crustal structure of the Dead Sea Basin (DSB) from a receiver function analysis, Geophys. J. Int., 184, 463-476, doi:10.1111/j.1365-246X.2010.04853.x.

Motaghi, K., E. Shabanian, F. Kalvandi; 2017, Underplating along the northern portion of the Zagros suture zone, Iran, Geophys. J. Int., 210, 375-389, https://doi.org/10.1093/gji/ggx168.

Motaghi, K., Tatar, M., Priestley, K., Romanelli, F., Doglioni, C., Panza, G.F., 2015, The deep structure of the Iranian Plateau, Gondwana Research, 28, 407-418,https://doi.org/10.1016/j.gr.2014.04.009.

Mottaghi, A.A., Rezapour, M., Korn, M., 2013, Ambient noise surface wave tomography of the Iranian Plateau, Geophys. J. Int., 193, 452-462, https://doi.org/10.1093/gji/ggs134

Movaghari, R., and G Javan Doloei, 3-D crustal structure of the Iran plateau using phase velocity ambient noise tomography, Geophysical Journal International, Volume 220, Issue 3, March 2020, Pages 15551568, https://doi.org/10.1093/gji/ggz537

Park, Y., A. A. Nyblade, A. J. Rodgers, and A. Al-Amri (2007), Upper mantle structure beneath the Arabian Peninsula and northern Red Sea from teleseismic body wave tomography: Implications for the origin of Cenozoic uplift and volcanism in the Arabian Shield, Geochem. Geophys. Geosyst., 8, Q06021, doi: 10.1029/2006GC001566.

Park, Y., Nyblade, A. A., Rodgers, A. J., and Al-Amri, A. (2008), S wave velocity structure of the Arabian Shield upper mantle from Rayleigh wave tomography, Geochem. Geophys. Geosyst., 9, Q07020, doi:10.1029/2007GC001895.

Paul, A., Hatzfeld, D., Kaviani, A., Tatar, M., \& Péquegnat, C. (2010). Seismic imaging of the lithospheric structure of the Zagros mountain belt (Iran). Geological Society of London, Special Publication, 330(1), 5-18. https://doi.org/10.1144/SP330.2.

Paul, A., Kaviani, A., Hatzfeld, D., Vergne, J. and Mokhtari, M. (2006), Seismological evidence for crustal-scale thrusting in the Zagros mountain belt (Iran). Geophys. J. Int., 166: 227-237. doi:10.1111/j.1365-246X.2006.02920.x. 
Pilia S., Jackson A. J., Hawkins R., Kaviani A., Ali M. (2020). The southern Zagros collisional orogen: new insights from transdimensional-trees inversion of seismic noise. Geophysical Research Letters. https://doi.org/10.1029/2019GL086258

Pirouz, M., Avouac, J-P., Gualandi, A., Hassanzadeh, J., Sternai, P., 2017, Flexural bending of the Zagros foreland basin, Geophysical Journal International, Volume 210, Issue 3, 1659-1680, https://doi.org/10.1093/gji/ggx252.

Portner, D.E., Delph, J.R., Biryol, C.B., Beck, S.L., Zandt, G., Özacar, A.A., Sandvol, E., Türkelli, N., 2018, Subduction termination through progressive slab deformation across Eastern Mediterranean subduction zones from updated P-wave tomography beneath Anatolia. Geosphere; 14 (3), 907-925. doi: https://doi.org/10.1130/GES01617.1.

Priestley, K., McKenzie, D., 2013, The relationship between shear wave velocity, temperature, attenuation and viscosity in the shallow part of the mantle, Earth and Planetary Science Letters, 381, 78-91, https://doi.org/10.1016/j.epsl.2013.08.022.

Priestley, K., McKenzie, D., Barron, J., Tatar, M., \& Debayle, E. (2012). The Zagros core: Deformation of the continental lithospheric mantle. Geochemistry, Geophysics, Geosystems, 13, Q11014. https://doi.org/10.1029/2012GC004435

Rastgoo, M., Rahimi, H., Motaghi, K., Shabanian, E., Romanelli, F., Giuliano F. Panza, G.F., 2018, Deep structure of the Alborz Mountains by joint inversion of $\mathrm{P}$ receiver functions and dispersion curves, Physics of the Earth and Planetary Interiors, 277, 70-80, https://doi.org/10.1016/j.pepi.2018.01.011.

Reilinger, R., and McClusky, S., 2011, Nubia-Arabia-Eurasia plate motions and the dynamics of Mediterranean and Middle-East tectonics, Geophysical Journal International, 186, 971-979, https://doi.org/10.1111/j.1365-246X.2011.05133.x.

Ritsema, J., \& Allen, R. M. (2003). The elusive mantle plume. Earth and Planetary Science Letters, 207, 1- 12. https://doi.org/10.1016/S0012-821X(02)01093-2

Rodgers, A. J., Walter, W. R., Mellors, R. J., Al-Amri, A. M. and Zhang, Y. (1999), Lithospheric structure of the Arabian Shield and Platform from complete regional waveform modelling and surface wave group velocities. Geophys. J. Int., 138: 871-878. doi:10.1046/j.1365-246x.1999.00918.x.

Sabra, K. G., P. Gerstoft, P. Roux, W. A. Kuperman, and M. C. Fehler (2005), Surface wave tomography from microseisms in Southern California, Geophys. Res. Lett., 32, L14311, doi:10.1029/2005GL023155.

Salaün, G., Pedersen, H. A., Paul, A., Farra, V., Karabulut, H., Hatzfeld, D., et al. (2012). High-resolution surface wave tomography beneath the Aegean-Anatolia region: Constraints on upper-mantle structure. Geophysical Journal International, 190(1), 406-420. https://doi.org/10.1111/j.1365-246X.2012.05483.x.

Schaefer, J. F., Boschi, L. and Kissling, E. (2011), Adaptively parametrized surface wave tomography: methodology and a new model of the European upper mantle. Geophysical Journal International, 186: 1431-1453. doi:10.1111/j.1365-246X.2011.05135.x.

Seber D. Vallve M. Sandvol E. Steer D. Barazangi M., (1997). Middle-East tectonics: applications of geographical information Systems (GIS), GSA Today, 7, 1 - 5.

Şengör A.M.C. Altiner D. Cin A. Ustaömer T. Hsü K.J., 1988, Origin and assembly of the Tethyside orogenic collage at the expense of Gondwana Land, in Gondwana and Tethys, Geol. Soc. London Spec. Pub., Vol. 37, pp. 119 -181, eds Audley-Charles M.G. Hallam A., Geological Society, London, https://doi.org/10.1144/GSL.SP.1988.037.01.09.

Shabanian, E., O. Bellier, L. Siame, N. Arnaud, M. R. Abbassi, and J.-J. Cochemé (2009), New tectonic configuration in NE Iran: Active strike-slip faulting between the Kopeh Dagh and Binalud mountains, Tectonics, 28, TC5002, doi: 10.1029/2008TC002444. 
Shad Manaman, N., Shomali, H., and Hemin Koyi, H., 2011, New constraints on upper-mantle S-velocity structure and crustal thickness of the Iranian plateau using partitioned waveform inversion, Geophys. J. Int., 184, 247-267, https://doi.org/10.1111/j.1365-246X.2010.04822.x

Shapiro N.M., Campillo M. Emergence of broadband Rayleigh waves from correlations of the ambient seismic noise. Geophys. Res. Lett. 2004;31:L07614. doi:10.1029/2004GL019491.

Simmons, N. A., Myers, C. S., Johannesson, G., Mazel, E., \& Grand, S. P. (2015). Evidence for long-lived subduction of an ancient tectonic plate beneath the southern Indian Ocean. Geophysical Research Letters, 42(21), 9270-9278. https://doi.org/10.1002/2015GL066237.

Simmons, N. A., S. C. Myers, and G. Johannesson (2011), Global-scale P wave tomography optimized for prediction of teleseismic and regional travel times for Middle-East events: 2. Tomographic inversion, $\mathrm{J}$. Geophys. Res., 116, B04305, doi: 10.1029/2010JB007969.

Stöcklin, J. 1968. Structural history and tectonics of Iran: a review. American Association of Petroleum Geologists Bulletin 52, 1229-58, doi:10.1306/5D25C4A5-16C1-11D7-8645000102C1865D.

Stoeser, D. B., and V. E. Camp (1985), Pan-African microplate accretion of the Arabian Shield, Geol. Soc. Am. Bull., 96, 817-826. doi: 10.1130/0016-7606(1985)96<817:PMAOTA>2.0.CO;2.

Tang, Z., Julià, J., Zahran, H., Mai, P. M., 2016, The lithospheric shear-wave velocity structure of Saudi Arabia: Young volcanism in an old shield, Tectonophysics, 680, 8-27, https://doi.org/10.1016/j.tecto.2016.05.004.

Tang, Z., Mai, P. M., Julià, J., \& Zahran, H. (2019). Shear velocity structure beneath Saudi Arabia from the joint inversion of $\mathrm{P}$ and $\mathrm{S}$ wave receiver functions, and Rayleigh wave group-velocity dispersion data. Journal of Geophysical Research: Solid Earth, 124. https://doi.org/10.1029/2018JB017131.

Tang, Z., P. Martin Mai, Sung-Joon Chang, Hani Zahran, 2018, Evidence for crustal low shear-wave speed in western Saudi Arabia from multi-scale fundamental-mode Rayleigh wave group-velocity tomography, Earth and Planetary Science Letters,495, 24-37, https://doi.org/10.1016/j.epsl.2018.05.011.

Tkalčić, H., M. E. Pasyanos, A. J. Rodgers, R. Gök, W. R. Walter, and A. Al-Amri (2006), A multistep approach for joint modeling of surface wave dispersion and teleseismic receiver functions: Implications for lithospheric structure of the Arabian Peninsula, J. Geophys. Res., 111, B11311, doi: 10.1029/2005JB004130.

Vanacore, E.A., Taymaz, T., Saygin E. (2013), Moho structure of the Anatolian Plate from receiver function analysis, Geophysical Journal International, 193, 329-337, https://doi.org/10.1093/gji/ggS117.

Warren L.M., Beck S.L., Biryol C.B., Zandt G., Özacar A.A., Yang Y., 2013, Crustal Velocity Structure of Central and Eastern Turkey from Ambient Noise Tomography, Geophys. J. Int., 194, 1941-1954, https://doi.org/10.1093/gji/ggt210.

Wessel, P., W. H. F. Smith, R. Scharroo, J. Luis, and F. Wobbe, Generic Mapping Tools: Improved Version Released, EOS Trans. AGU, 94(45), p. 409-410, 2013. doi:10.1002/2013EO450001.

Yao, Z., Mooney, W. D., Zahran, H. M., and Youssef, S. E.-H. (2017), Upper mantle velocity structure beneath the Arabian shield from Rayleigh surface wave tomography and its implications, J. Geophys. Res. Solid Earth, 122, 6552- 6568, doi:10.1002/2016JB013805.

Zonenshain, L.P., and Le Pichon, X., 1986, Deep basins on the Black Sea and Caspian Sea as remnants of Mesozoic back-arc basins, Tectonophysics, 123, 181-211, https://doi.org/10.1016/0040-1951(86)90197-6.

Zor, E., E. Sandvol, C. Gürbüz, N. Türkelli, D. Seber, and M. Barazangi (2003), The crustal structure of the East Anatolian plateau (Turkey) from receiver functions, Geophys. Res. Lett., 30, 8044, doi: 10.1029/2003GL018192, 24. 


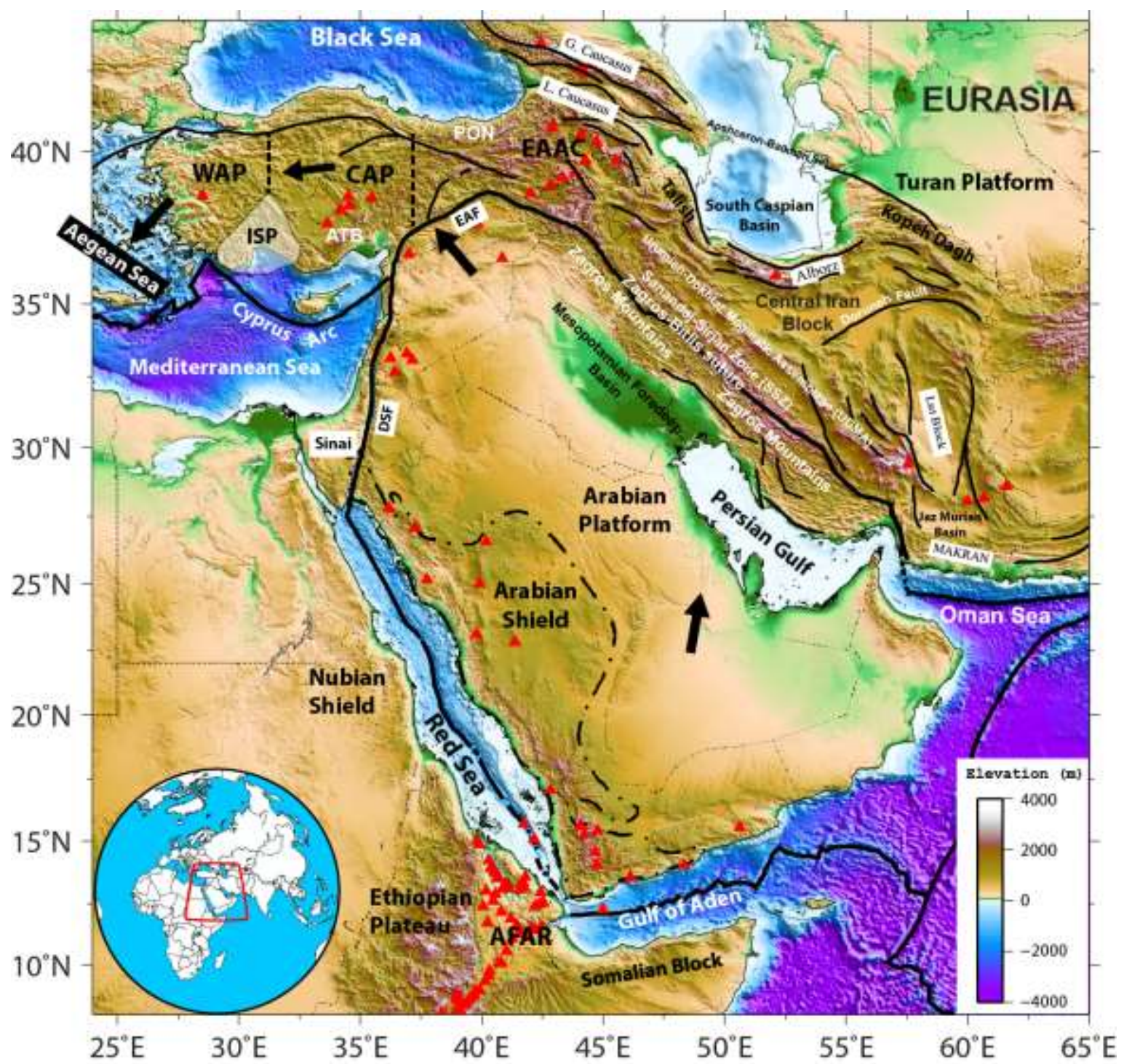

Figure 1. Major tectonic features of the Middle East superimposed on a topographic map. Red triangles show locations of Quaternary volcanism. Thick black arrows show the direction of motion relative to Eurasia. EAAC: East Anatolian Accretionary Complex; CAP: Central Anatolian Plateau; WAP: Western Anatolian Province; NAF: Northern Anatolian Fault; EAF: Eastern Anatolian Fault; PON: Pontides; ATB, Anatolide-Tauride Block; ISP: Isparta Angle; DSF: Dead Sea Fault, SSZ: Sanandaj-Sirjan Zone, UDMA: Urumieh-Dokhtar Magmatic Arc, L. Caucasus and G. Caucasus for Lesser and Greater Caucasus, respectively.(after Okay \& Tüysüz 1999; Pourteau et al., 2010, van Hinsbergen, and Schmid, 2012). 


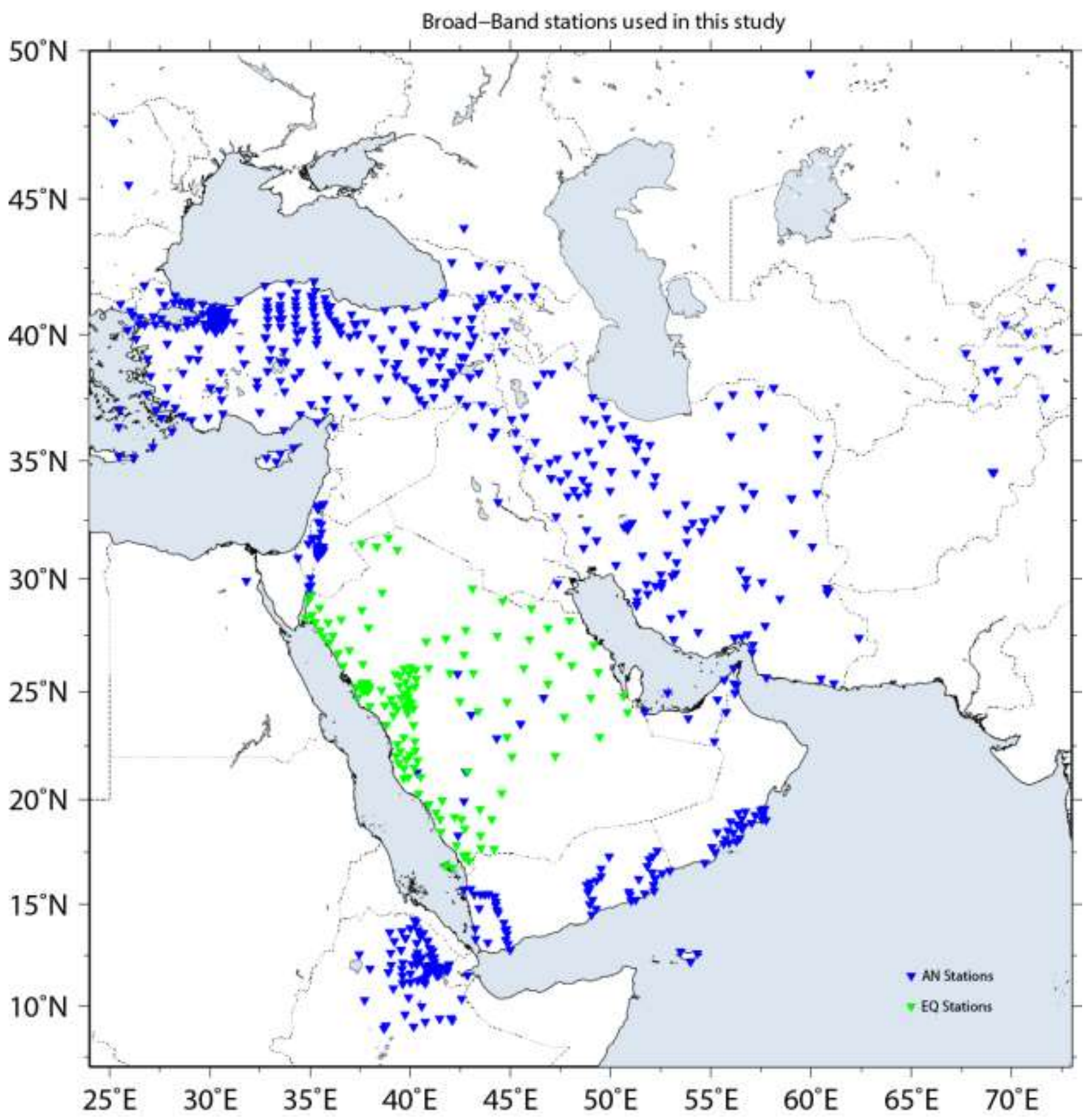

Figure 2. Location map of stations used in this study. Blue triangles are stations used in ambientnoise analysis (AN). Green triangles indicate stations in Arabia providing surface-wave dispersion data from regional earthquake waveforms (EQ). 

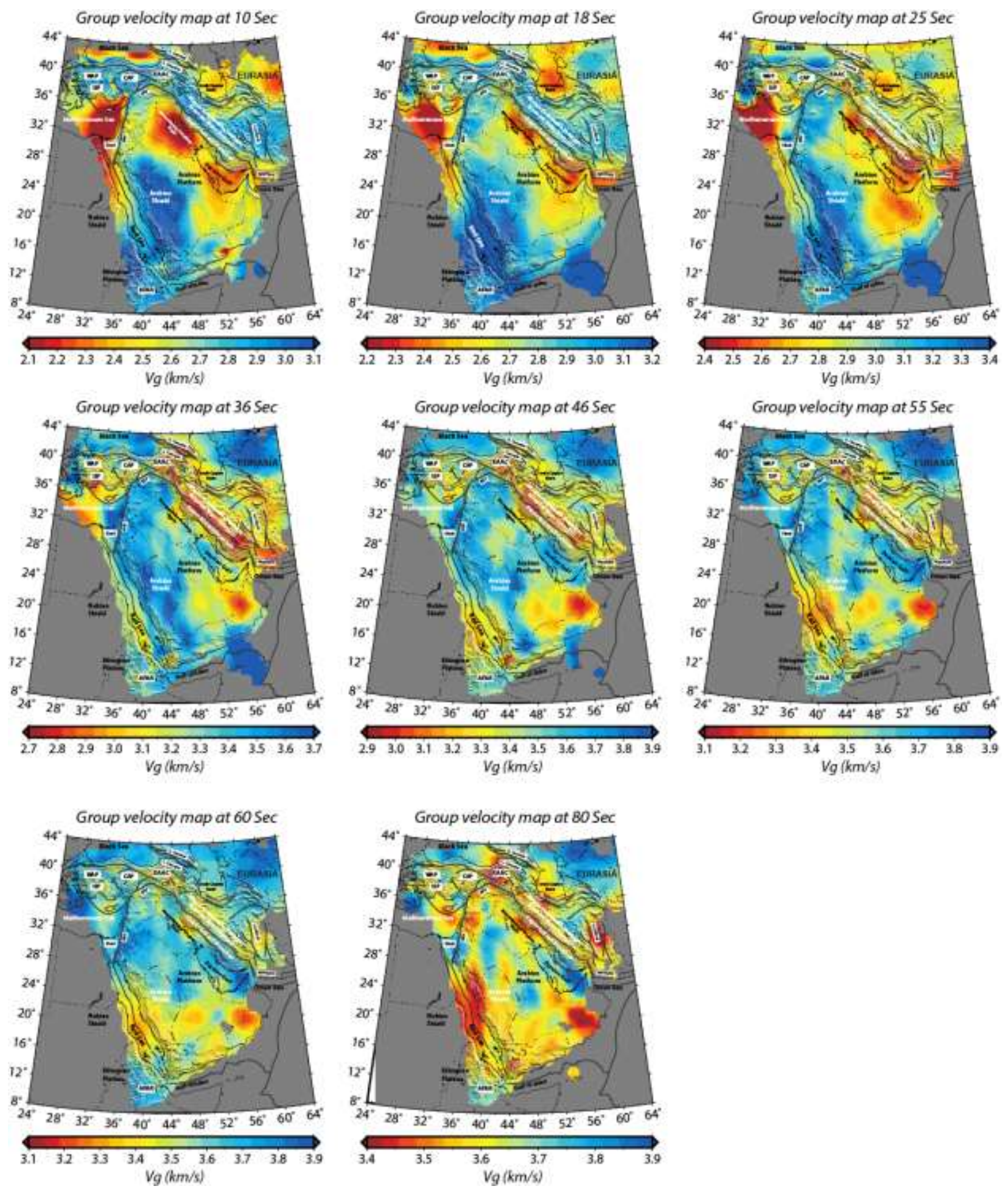

Figure 3. Examples of group-velocity maps at representative periods of 10, 18, 25, 36, 46, 55, 60 and $80 \mathrm{~s}$. According to the sensitivity kernels of Figure S8, the group velocity at these periods is representative of $\mathrm{Vs}$ at depths $8,15,25,35,45,55,70$ and $90 \mathrm{~km}$, respectively. We only show regions with more than 10 raypaths per cell, and we masked out the unresolved regions based on the synthetic tests (Figure S5). 

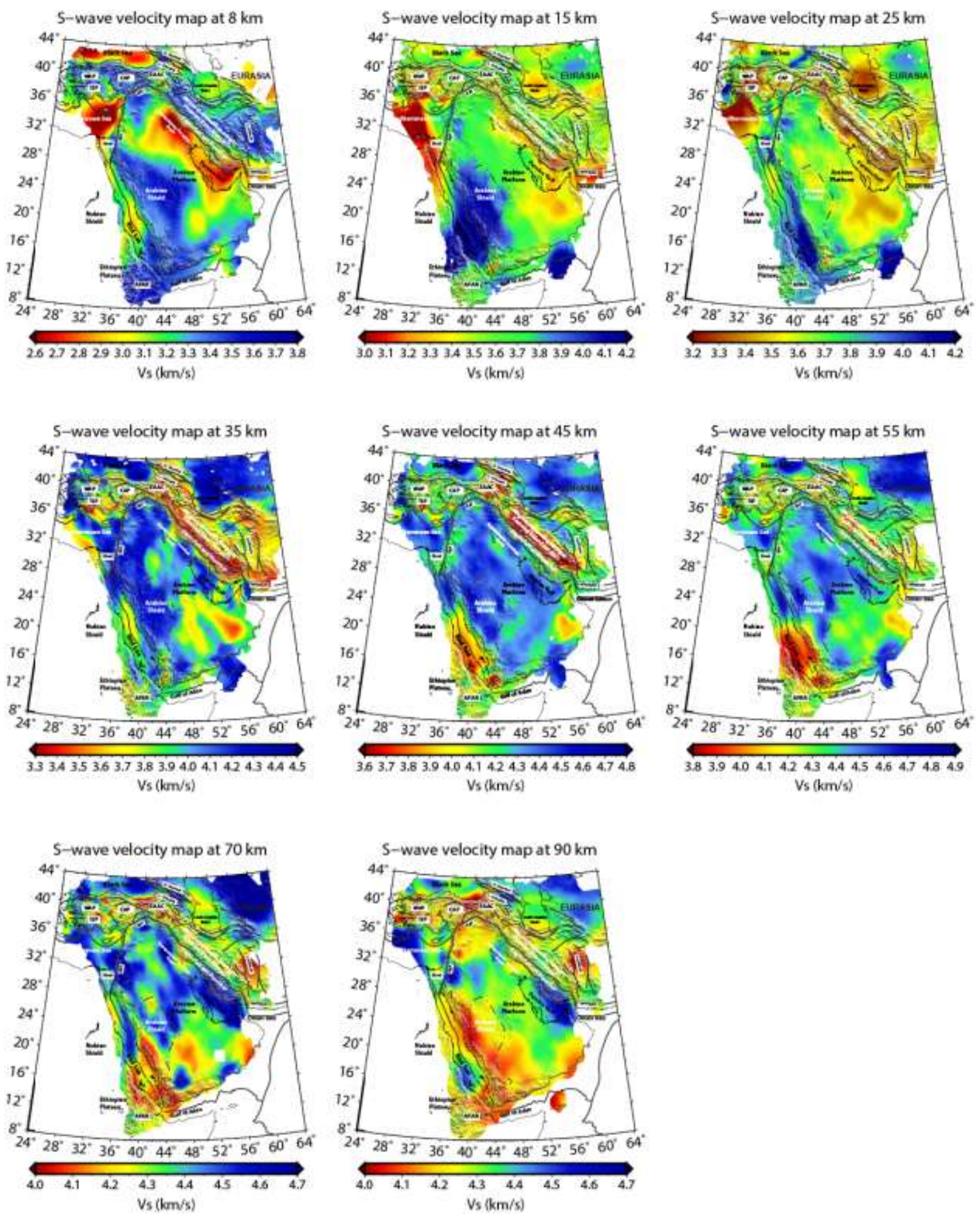

Figure 4. Examples of shear-wave velocity maps at depths 8, 15, 25, 35, 45, 55, 70 and $90 \mathrm{~km}$ covering the whole Middle East. Note that color scale changes for each map to enhance lateral velocity contrasts. 
a) Moho depth map this study

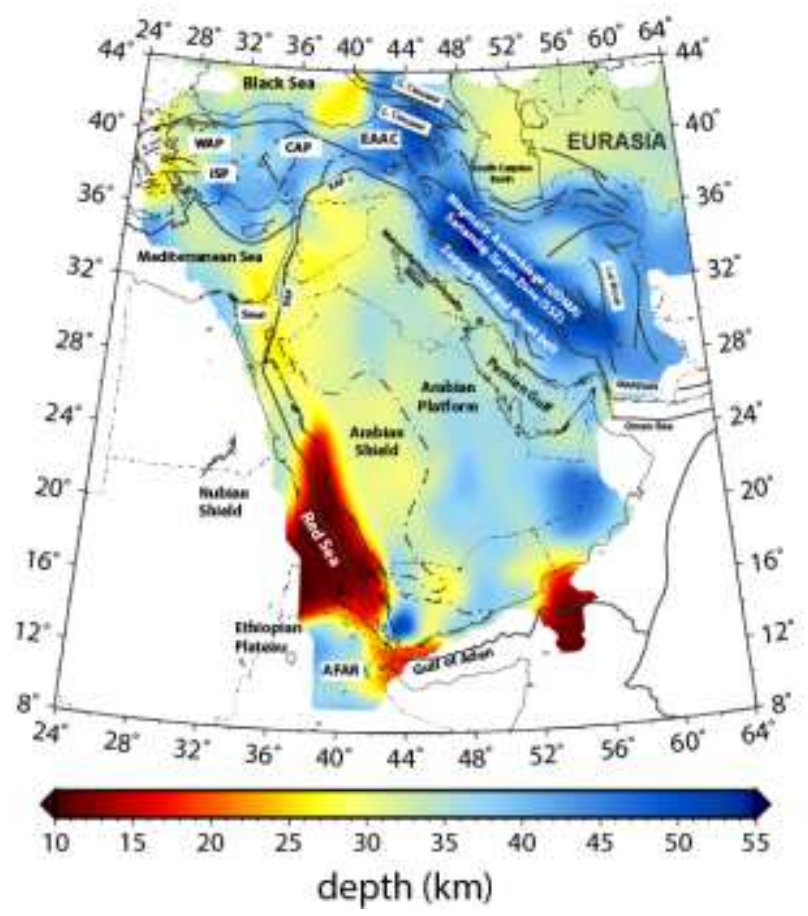

b) Moho depth map CRUST1.0

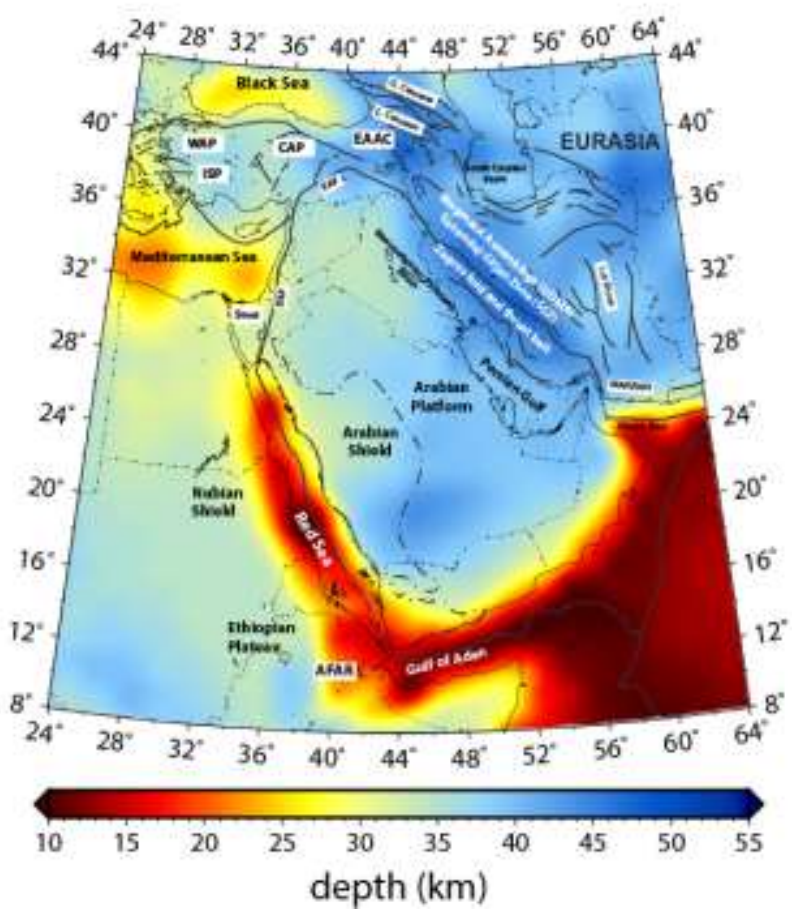

Figure 5. Comparison of the Moho depth map obtained in this study with the Moho map from CRUST1.0 (see text for definition of Moho). 

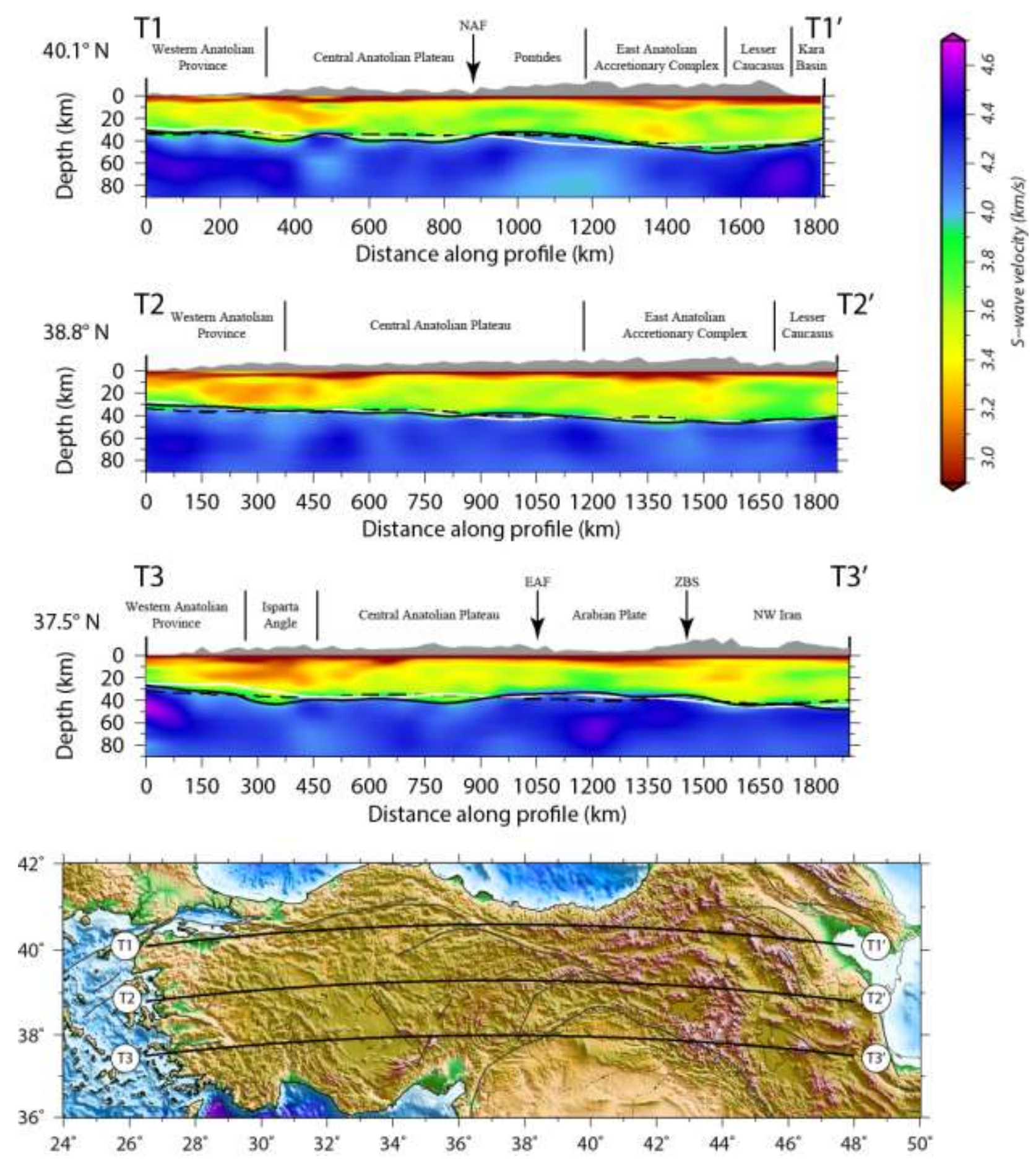

Figure 6. Vertical slices of shear-wave velocity along profiles T1-T3 across Anatolia. The solid and dashed black lines indicate Moho depth from this study and CRUST1.0, respectively. The Moho obtained in the receiver function study of Karabulut et al. (2019) is also shown as a dashed white line for comparison. Vertical exaggeration: 3. Additional sections are shown in Figure S9. 

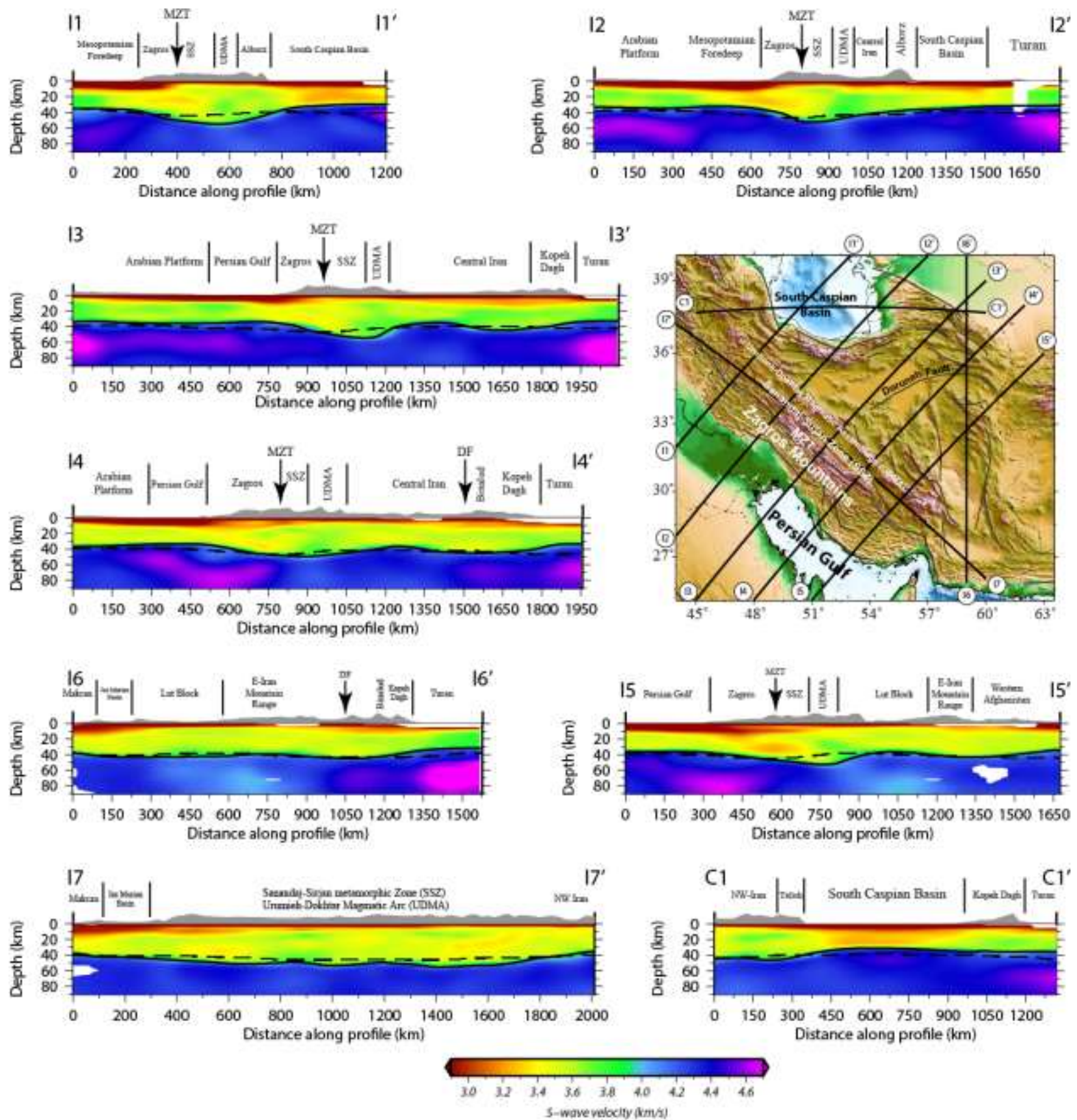

Figure 7. Vertical slices in the Vs model along profiles I1-I7 and C1 across the Iranian Plateau, Zagros and Caspian Sea. The solid and dashed black lines indicate the Moho depth from this study and CRUST1.0, respectively. Vertical exaggeration: 3. 

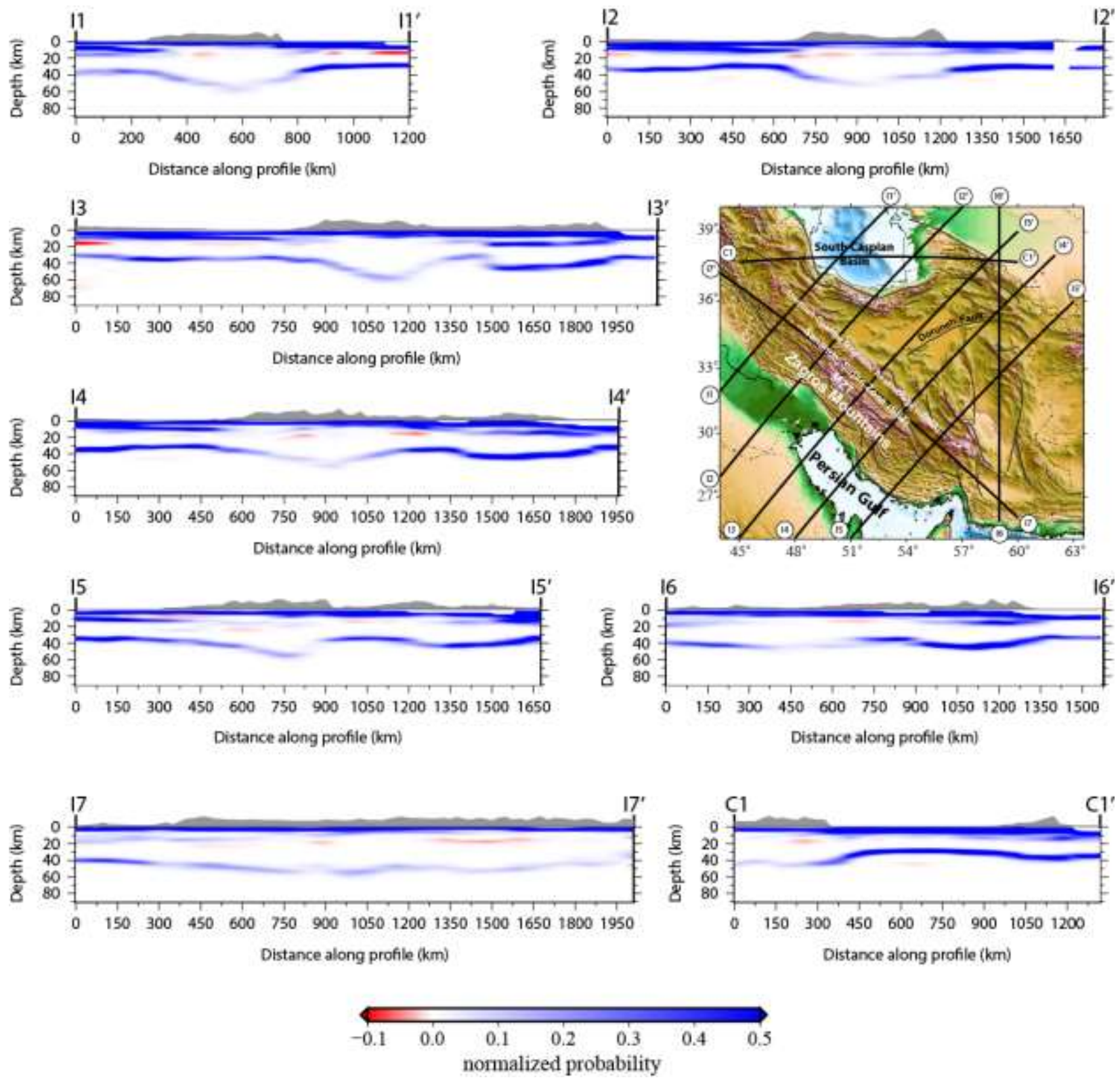

Figure 8. Vertical slices of interface probability density across the Iranian Plateau and Zagros along the same profiles as in Figure 7. The color scale of the vertical slices indicates the probability of occurrence of a layer boundary at a given depth. The blue color indicates boundaries of low-to-high velocity from surface to depth. The red color indicates a reversevelocity gradient, i.e. the top of a low-velocity layer. 

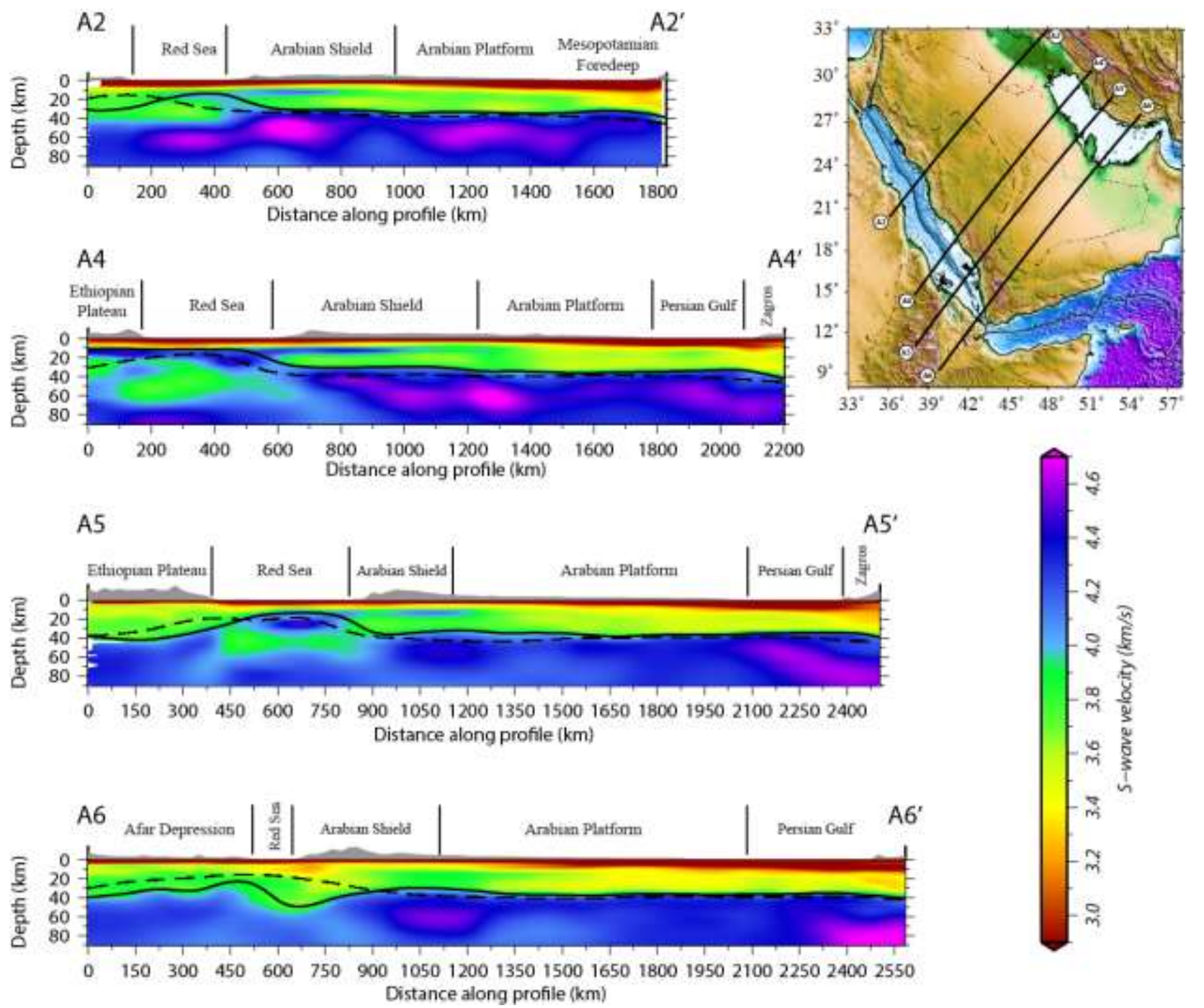

Figure 9. Same as Figure 7 for profiles A2, A4, A5, and A6 across the Arabian Plate, Red Sea and Afar. 
Table 1: Range of variations in the thickness and velocity in each layer of the initial random models.

\begin{tabular}{|l|l|l|}
\hline Layer & Thickness $(\mathrm{km})$ & Vs $(\mathrm{km} / \mathrm{s})$ \\
\hline Sediments & $1-10$ & $1.0-2.9$ \\
\hline Crust 1 & $2-30$ & $2.3-3.7$ \\
\hline Crust 2 & $5-30$ & $2.6-3.5$ \\
\hline Crust 3 & $10-30$ & $3.4-4.0$ \\
\hline Uppermost Mantle & & $0.8-1.2$ times of the IASP91 velocity \\
\hline
\end{tabular}

